Letras, Lima 48 (84-85): 135-201, 1976.

\title{
Envés y reflexión de lo huachafo
}

\author{
(Jorge Miota: vida y obra)
}

WILLY F. PINTO GAMBOA

\section{1.-ENVES Y REFLEXION DE LO HUACHAFO}

I. Lo que trae el siglo $X X$

En el lapso del 79 al nuevo siglo, el Perú entre otros hechos supera con dificultad la crisis que le había traído la derrota. "La guerra con Chile no sólo derramó nuestra sangre, expuso a la luz del sol nuestra lepra", había manifestado acusativo don Manuel González Prada. En eb sur, en Arequipa, turbas regimentadas queman en monigotes, en un mittin, a Francisco Mostajo, a José Angel Escalante y a Mariario Lingo Urquieta, que à su turno animaban EI Ariete. Aspera polémica entre el pierolismo y EI Comercio: "Ustedes y sus amigos (el civilismo) están matando al Perú", enrostrará al decano nacional, don Nicolás de Piérola. El autor de Horas de lucha, se aleja de la "Unión Nacional", el radicalismo en la escena de la política peruana, "porque conocía a los hombres. No había en ellos ni ideas ni ideales y sí una ausencia total de lealtad y honradez -como "confiesa" a Félix del Valle en un reportaje dos años antes de su muerte. Hace su ingreso en la verba popular el término huachafa, que una realidad sui generis le había llevado a inventar a Jorge Miota; término feliz recogido a posteriori para el mundo literario por la escritura, "esa haragana artillería hacia lo invisible", según definición de Jorge Luis Borges.

\section{Semiburguesía y sociedad}

Es evidente que la Guerra del Pacífico, con su secuela de ocupación y de despojo, generó una honda crisis, tanto en la aristocra- 
cia conservadora y elitista como en la burguesía plutocrática, en cuanto a clases dirigentes; pero, es evidente también, que su redomado manejo del poder, o el usufructo, en contubernio con los reiterados golpismos sediciosos, en detrimento de legítimas vocaciones populares, una vez pasada la contienda, hizo que estos grupos siguieran manteniendo la capacidad de decisión en lo político, lo social y lo económico; bien dice el hecho, que a caballo entre el siglo XIX y el siglo XX gobierne la nación don Eduardo de Romaña, arequipeño, ingeniero de británica educación y uno de los cuatro ricos hombres del Perú. Advirtiéndose, para el caso, que la vigencia de estos grupos representó más de las veces el uso egoísta de logros y hallazgos de muchas etapas de nuestra historia nacional.

Con referencia a esta situación, la fisonomía de la sociedad limeña se fue ahormando a los apetitos y exclusiones del poder detentador, de tal suerte que el espectro social del país se perfilaba en la capital de una manera precisa y definida; después de todo ya resulta común el marchamo de centralismo de la "tres veces coronada villa", además de su reconocido monopolio político y administrativo.

En lo que atañe a la hegemonía capitalina, cabe citar dos notas al respecto; la conclusión a la que llega Dávalos y Lisson en un estudio acerca del periodo de Balta, en el sentido de que én el Perú "los apasionamientos y los intereses de la Costa, especialmente los de Lima[...] determinaban los hechos" y; la inquietud de don Juan José Salcedo, ministro de Hacienda en 1859, quien denunciaba al Congreso "la influencia que ejerce la capital cuando la ma yor parte de la población vive del tesoro público", como vemos, la seducción de "La ciudad de los reyes", a pesar de su precariedad e indolencia, "eso ae antigua datapnverso"

Todo era pues propicio, según se ve, para que en el ambiente, - al lado de las capas plutocráticas y aristocratizantes, que habían hecho de Lima su fortín para el uso de mecanismos político-culturales, se fuese plasmando en su estructura social, aquel nivel semiburgués más o menos impreciso, llamado comúnmente clase media.

\section{Tipología naturalista}

A la colonial "Lima cuadrada" la rodea a fines del 900, una existencia orillera hecha de necesidades, apariencias y medianías, existencia no ajena al asedio periodístico de Iorge Miota, siguiendo explícitás prescripciones de Emilio Zola y Guy de Maupassant.

"Flaner es un arte, -afirmará Miota- caminad, recorred la ciudad entera, sus calles, sus barrios; sorprenderla en las diferentes horas del día y entonces si tenéis carácter estudioso, haréis insensiblemente un acopio de observaciones que os pondrán en posesión de ella, de sus usos y costumbres, de sus tipos...". En esta 
línea con el autor de Bola de sebo, admite que cada barrio guarda un rasgo inédito del mundo urbano. Así El barrio chino, con sus orientalismos, es la mueca exótica y cosmopolita. Vericuetos aptos para garitos, la compra-venta de birlados avíos, el opio y el quinqué. Santuarios, extrañas divinidades búdicas y en el "Odeón", melodramas más extraños todavía. Fondines de pringue y pitanzá magra. Allí buhoneros, vendedores de golosinas chirles, estrambóticas trenzas, curiosas prendas, en suma, toda la resaca del abuso terrateniente en la humanidad de coolíes y de canacas desarraígados. Abajo el puente, es la expresión más homogénea del espíritu popular, donde escondida entre "San Lázaro" y "Los Descaizos", suele vivir la chanza de Atanasio Fuentes y Ricardo Palma. A la distancia, pecaminosa y dispar al "Callejón de Romero", el "Cantagallo", tierra de mala nota y de quilombos: curso habitual de la cantuja perdularia en la voz del descaro gandul ("Sono dadero ensendieceiseis basoños y me planero burulare de la feligree chontana": "Soy ratero desde hace dieciséis años y me gusta burlarme de los señores"). Más allá las turbias piscinas de "Piedra Liza". Es un barrio que fácilmente se enciende de juerga y zambra, sobre todo por "entendíos" y donde Lima tumultuosa se escabulle hacia las corridas, atravesando "La Cecina", "La Luna" y "El Sol". entradas del coso de Acho. Barbones, memoria de Lima añeja, ge. nuino arrabal cubierto por la pátina. Aspillados y derruidos cuarteles mirando El Agustino, horadado ya por las faenas en las canteras. Próximo a los fortines, un ambiente labriego: yermos potreros, cultivos de panllevar y casucas pluricolores. El Cercado, obstinada faz provinciana con presuntuosos distingos. Mansiones y viviendas enclavadas en huertecillos, donde se pretende privacidad. Vecinas, las récogidas delhëBuen Pastor". Cinco Esquinas y Cocharcas, expresión del hacinamiento urbano. "Los Naranjos". caserones y zaguanes, tambos y conventillos y en la ruta de "Pampa de Lara", herrerías: fragua, yesca y bigornia. El "Puerto de Guinea": black-town, laberintos de culinaria mandinga, gente de bullanga, peritos en la gallística y en la navaja. En "Buenos Aires", sombrererías y recreos destartalados para los infantes, mientras que en la Iglesia de Cocharcas está el huerto frailuno, donde reposa abotagado el chantre. El Camal, cochambre y mugre, el aparato estomacal de la ciudad. Taifa de reseros, rematistas y matarifes, regateras y marchantes de la merca visceral para la cocinería criolla. Monserrate, zona de acarreo. Estación, furgones y andenes. Iglesia, plaza, tenduchos y pulperías; hacia el camal, fábricas, curtiembres y andurriales atestados de zopilotes. Así vería Jorge Miota, ? discípulo fiel del zolaense naturalismo, el "vientre" y los personajes periféricos capitalinos - "con su tontería de la que suelen salir como de una fosa"- según apunte novelístico de G.H. Chesterton sobre la clase media. 
Fue allí, en ese fajín suburbano donde Miota descubre "el amor solitario de una Bovary en alguna casa huerta de Barrios Altos", o en el tránsito de Bajo el Puente "desde donde lanza la Diosa Minerva el surtido de sus percalinas", o en torno a San Lázaro: "parroquia de óleos y matrimonios cursis", el tipo de la huachafa, en una realidad donde precisamente el sistema establecido, con sus cortapisas y diferencias, daba vida vacua y rutinaria a una clase media horra de heroicidad y de sentido.

\section{Esteticismo modernista}

El Perú representó en el pasado colonial uno de los más significativos emporios económicos donde agro y yacimientos propi. ciaban ingentes riquezas en favor de la metrópoli, situación que en cierta medida se traducía formalmente en la capital, a través de una atmósfera de lujo, de dispendio y de boato. Así lo verificará Alonso Carrió de la Vandera -fisgón notorio-, cuando en su opinión encontraba a las damas platenses "más pulidas de todas américas españolas", aunque no comparables "en lo costoso" de sus vestimentas a la que usaban las féminas limeñas.

Alarde del eterno femenino autóctono, puesto en evidencia por Garcilaso de la Vega el Inca, en sus Comentarios, bajo el rubro de "Diferencia de papagayos, y su mucho hablar", donde relató la historia de aquella indígena que escoltada por "tres o cuatro criados", transitaba por una calle principal de Potosí "haciéndose mucho de la señora Palla, que son de sangre real", sin advertir la presencia de un parlerópapagayo, qué tenía como mejor gracia, la identificación del rango de los indios, por los tocados que llevaban; fueran Collas, Yungas, Huairu, Quechua. Lo cierto del caso es que en viéndola el pajarraco le espetó un chilloso Huairu... Huairu... Huairu, "que es una nación de gente vil y tenida en menos que otras", -según nuestro cronista-, descubriéndola con aparato, para el asombro y burla de los viandantes, ganándose de esta manera la guacamaya, el apóstrofe despectivo de zupay de la postiza dama.

En relación con el modernismo en el Perú, ya resulta reiterado su sedimento ecléctico; para el caso el $3^{\text {o mandamiento del }}$ decálogo de Chocano, inserto en La Neblina: "Oír misa con devoción en los altares de Hugo (poeta), Ibsen (dramaturgo) y Zola (novelista), lo mismo que el lema en Fiat Lux "en el arte caben todas las escuelas como en un rayo de sol todos los colores", es a todas luces elocuente. No obstante la rara simbiosis postulada por el autor de Alma América, es posible hallar también en su poética, un vago afám, a su modo esteticista. En otra instancia, el modernismo americano, al que no fue ajeno Jorge Miota, no sólo reivindica una estética en la forma literaria sino inclusive, en aque- 
llo que denominó Rubén Darío con marcada certidumbre "la comprensión de la estética de la existencia[...], el don incomparable del buen gusto". Frente a esta vocación de excelencia, resultaba indudable que todo estilo de vida que se preciase espúreo o ilusorio, tenía que aparecer a la retina modernista, como una práctica cursi, inelegante y presuntuosa, cúmulo de huachafismo en suma. El término es pues, en este sentido, como revelador de una situación reñida con la estética, nuestro más singular aporte al habla americana modernista.

\section{Auge y presencia de lo huachafo}

Jorge Miota no confiere al vocablo un sentido de escarnio o de dicterio, antes bien en él reflejó un mundo que dolorosamente fermentaba sin presteza en el entresijo de una escala social individualista e indolente; a través de su visión naturalista, teñida de prototipo a lo Zola -recordemos Mouset el financista, Esteban el obrero y Naná la cortesana, por ejemplo- que captaba no sólo una clase sino una época de nuestra propia rélidad; $d^{\prime}$ après nature, como lo subrayara al tratar El Cajetilla en "Tipos bonaerenses", sociedad y paradigmas que fueran cribados a la vez por la mira alquitarada de un modernismo aprendido de Rubén y que iba a dar como resultado la aprehensión de lo huachafo.

Por algo advirtió un cronista de 1903, que la etimología más que un modismo era "todo un símbolo de cierta clase femenina" y "un calificativo que responde a toda_una idiosincrasia social", cuyo término se adecuaba a todas aquellas niñas que con un fondo cursi, transparentan en sus personas, en sus trajes, en sus cuitas, en sus lazos, en sūs zapatos la didiosincrasia de sus barrios; que trascienden y que finalmente tanto en la galimatía de sus trajes como en la de sus espíritus, está retratado el esfuerzo doloroso de "parecer lo que no son".

La voz hace tiempo que ha ingresado al campo literario, su presencia se comprueba en su temática reiterada que llega aún a la caricatura por el lápiz de Challe y Málaga Grenet, inclusive arriba a la publicidad, para el gusto del consumo; al respecto valga el dato sobre un concurso que auspiciaba en 1920 la International Publicity Co. en el semanario Hogar, en busca del decálogo huachafo.

\section{a) Colombianismo-Peruanismo}

Sobre esta controversia Martha Hildebrandt hace hincapié acerca de lo reciente de la palabra en nuestro medio.

La vitalidad del peruanismo huachafo medida por la riqueza de sus derivados, es, como se ve, muy grande, sin embargo, parece que se trata de un uso relativamente nuevo. 
A propósito, en Calles de Lima y meses del año, José Gálvez establecía significativa dualidad.

Y Jorge Miota introductor del término huachafita con diferente sentido al colombiano guachafita por gresca, zalagarda o tremolina, aquí aplicada a la muchacha presuntuosa y cursilona, dengosa y melindrera.

En ese sentido concuerda con un hecho anecdótico que proporciona Estuardo Núñez y que aparece en Peruanismos.

Alrededor de 1890, llegó a Lima una modesta familia de emigrados colombianos (probablemente algún político exiliado y los suyos) y se avecinó en la calle del General, muy próxima al cuartel de Santa Catalina. Como en dicha familia se contaban unas jóvenes casaderas y atractivas, estas solían organizar frecuentes fiestas bastantes alegres a la que llamaban huachafas. La expresión fue bien acogida por los concurrentes a las fiestas, vecinos del barrio $\mathrm{y}$, sobre todo, oficiales del contiguo cuartel y con el tiempo las dueñas de casa, que tenían un apellido poco común y algo difícil, eran conocidas por el sobrenombre de huachafas. La denominación de la fiesta para aplicarse a sus organizadores que eran modestas muchachas de clase media, de cierta estrechez económica y que se esforzaban por aparentar ante sus invitados y vecinos más de lo que eran o tenían.

Precisamente Folusto Gastañeta Ten 1909 en Variedades, en el artículo "Huachafas y diputados" evidencia el sentido colombiano y la significación "adjudicadá a jorge Miota, a través de doña Caro, Etelvina y Corina, figuras boyantes del huachafismo.

Los diputados, ellos precisamente, no los congresistas en general, tienen en los círculos "huachafosos" más cartel que "Guerrita" entre la gente de coleta y que el padre Pérez entre las beatas de Lima.

Todo es que empiezan a funcionar las cámaras, funcionan las huachafas. Es decir, entran en funciones sociales.

No bien comienzan los diarios de la capital a anunciar la llegada del constituyente que cada provincia nos manda al Congreso, cuando tenemos, los que vivimos arrimados al periodismo, la mar de esquelas más o menos insinuantes, invitándonos para un "té de confianza", "un bailecito de amigos íntimos", o para unos "chicharrones" de costilla... de cerdo. Naturalmente cada misiva, trae la indispensable postdata concebida en estos términos: "No deje Usted venir con sus amigos de provincias". Estos amigos son los representantes a Congreso. 
Y hablando en plata no dejan de gustarles, iY muchol, estas reuniones a nuestros provincianos padres de la patria...

\section{b) Lo cursi, lo snob y lo huachafo}

Resulta curioso, por no decir lo menos, que la primera reflexión sobre el tema: "Tipos y costumbres: Las huachafas", aparezca en el mismo diario y en el mismo día (El Comercio, Lima, 19 de abril de 1903) en el que se inserta un artículo de Federico Blume, bajo el título de "Las señoritas cursis". Sobre género tan peculiar escribía "Balduque":

La autora de la carta no hacía por cierto envidiar al galón, porque es indudable que se trataba de una de las tantas señoritas cursis que habitan en casas de vecindad o en tiendecitas con puerta a la calle.

Probablemente esta Josefina pertenecía a la clase social de niñas pobres y cursis que en el rigor del invierno salen muy orondas con pastoras de paja adornadas con cintas verdes y pochones blancos y lucen en la canícula, boas de pieles y capus con vuelta de armiño...

En cuestión de modas, nadie supera en audacia a las señoritas cursis, porque la armónica combinación de los colores no entra para nada en el programa de sus chillonas toilettes y porque sus bórbaros asaltos contra la elegancia y el buen gusto, en materia de adornos, superan a las ricas coloraciones de un arco iris veraniego.

Pobrecitas! Ellas, como todas las hijas de Eva, se desviven por agradar ydéslumbrarin peró comolpor' lo general aprovechan de la indumentaria barata, de las casas de préstamo, resultan unas combinaciones en que el clasicismo y el modernismo chocan de una manera estruendosa.

En relación a la cursilería, no pocas veces se ha admitido su vecindad con lo huachafo. Verbigracia, para Rose Bercis en "Teoría y práctica de la elegancia. ¿Qué es la huachafería en el vestir?", la acentuación del elemento cursi resultaría primordial.

La huachafería es un modismo netamente peruano, expresa un signo marcado de cursilería e indica una absoluta demostración del mal gusto.

Sin embargo, Martha Hildebrandt no aventura plena identificación.

En nuestra habla familiar huachafo tiene el sentido aprox:mado de "cursi". 
En el reportaje "Encuentro con José Gálvez" de Enrique Labrador Ruiz, nuestro vocablo adquiere equivalencia, en la reiteración que hace el autor de Jardín cerrado.

En Colombia, guachafita significa tremolina. En el lenguaje culto y popular nuestro, no. Un huachafoso tal vez sería ol "picúo" de ustedes; y la huachafería, el conjunto, la modalidad de un grupo de gente pintoresca y detonante, cursi, cursi.

Como lo es para Enrique A. Carrillo, "Cabotín".

Huachafería, huachafo, huachafita. Para el lector que no sea limeño mazamorrero, los términos antedichos no tienen significado conocido. El huachafo corresponde al cursi, al cursi, castellano...

En lo que atañe a un contenido significativo, José Chioino coincide con "Cabotín" y por ende con José Gálvez.

Feliz anduvo el autor de la palabreja con que en Lima se azota las manifestaciones de la cursilería y el gusto desgraciado, en un radio que comprende desde un sombrero o una corbata, hasta un soneto o un editorial.

Luis Alberto Sánchez en un parágrafo autobiográfico de El Perú: retrato de un país adolescente, revela:

Cuando yo era joven, la ciudad se dividía en barrios tácitamente definias. "En eEl Chirimoyo" y La Victoria se encontraba gente de mediopelo y obreros. Reinaba la "huachafa", esa inefable flor de romántica cursilería...

Mientras que en el poema satírico "Decadentismo criollo", Federico Blume expresará tácitas discrepancias.

Así hablaba Tirifilo/ un poeta muy tranquilo/ un poeta muy tranquilo que debía / la comida que comía/ y bohemio y decadente y modernista/ siempre ocioso/ vanidoso,/ con ribetes de envidioso/ cursilón y huachafoso...

No lo entiende así Alberto Guillén en El libro de la democracia criolla, para quien lo cursi representa un ingrediente notable.

Además diré que el señor Vargas Vila es el más cursi de los escritores leídos y no leídos. No sólo es cursi, es huachafo. Huachafo en el Perú es el summum de lo cursi. Bueno, pues, huachafo es el señor Vargas Vila. 
El poeta Manuel Velásquez Rojas en Zoología poética de César Vallejo, incursionando en nuevos predios ha tocado lo concerniente al snobismo.

Considero que, snob, literalmente, es el que posee dinero pero no nobleza. $O$ sea el burgués sin refinamiento civilizado, que imita algunas acciones sin entender ni sentir los valores que estas acciones encarnan. No hay que confundir snob con huachafo. Este último término, creado en el Perú (se afirma que el periodista Jorge Miota lo difundió a principios de nuestro siglo), conserva su propia definición significativa. Huachafo es el que no posee dinero e imita (en vestimenta, conducta, acciones, etc.) a quien lo tiene. Es risible sin ser ridículo, porque agrega su propio ser (en el fondo desvalido) como defensa. Así, pues, el snob ("nuevo rico") cumple acciones sin sentirlas ni valorarlas...

Diversidad de ninguna manera compartida por Alfredo Cánepa Sardón, quien en 1940 desde las páginas de Jornada sostuvo que huachafería y snobismo eran idénticos:

sin más diferencia - To reitera en 1978- que la lingüística, pues uno era un peruanismo y el otro un anglicismo - de raíz latina- cuya posterior extensión a otros países había demostrado que el snob y su snobismo no fueron exclusivos de Inglaterra, sino que también aparecieron en todos los otros pueblos en los quee cundió el iqualitarismo, individualismo y democracia propios del liberalismo...

La vinculación entre lo cursi y lo huachafo es indudable, al menos en un recuento literario, como se puede constatar, observándose que la línea fronteriza entre ambos términos es sutil y engañosa; sobre aquel, Unamuno aseguró su origen navarro, ciudad "donde vivía una familia muy ridícula de apellido Sicur", el pueblo, inventor insuperable, trabucó el orden silábico fletando de esta suerte el adjetivo para gente de ridícula laya.

El significado de cursi suele más de las veces presentarse como una suerte de substratum de lo huachafo; como valioso material para un deslinde María Dolores Rebes y Francisco García Pavón, nos presentan en España en sus humoristas, un caracterizado fresco de lo cursi, que bien puede servir para una exacta fijación de lo huachafo.

Lo cursi[...] la figura central de estos episodios es la mujer, la mujer joven que, ante todo, quiere casarse para asegurar su vida. Ese acuciante deseo origina incidencias muy variadas y divertidas y melodramas deliciosos, siempre a costa 
de la mamá de la pobre muchacha... y, a veces, del papá. Todo arranca, naturalmente de la situación en que está colocada la mujer. Situación anómala, porque la tremenda limitación que para la mujer española supone no tener más horizonte que el matrimonio es algo que ya por entonces, se encuentra próximo a desaparecer en el mundo occidental. Se empieza, por aquellos años, a presentir entre nosotros que semejante limitación constituye un anacronismo. $Y$ ese estado colectivo de conciencia, aunque oscuro y difuso, basta para convertir el tema en materia de humor; antes, en el siglo XVII o XVIII, nadie se hubiera permitido tal osadía. Durante la segunda mitad del ochocientos han cambiado mucho las circunstancias y ya resulta ridículo que una joven de familia modesta pase estrecheces por el vano afán de guardar las apariencias. La clase media vive aún imitando como puede -muy pálidamente, huelga decirlo- las formas de existencia de la nobleza. Y, de acuerdo con ese patrón, no cabe otro remedio que mantener a los hijos en el hogar paterno, al abrigo de toda necesidad, hasta que llegue, por sus pasos contados, el matrimonio. Pero los ingresos de un solo hombre no alcanzan ya para cubrir las exigencias del hogar, cada día mayores. Se hace indispensable que la mujer de la clase media busque otras vías para resolver por sí misma su problema. Al avanzar el siglo XX, el ansiado camino será hallado - merced, en parte al movimiento feminista - en la oficina, en el laboratorio, en la Universidad y en nuevos patrones, en nuevas formas de existencia qué nada tendrán que ver con las de la nobleza.

Entre tanto, la situación permanece inalterable. Aunque se cuarteen "portodos lados, los viejos" moldes siguen en pie. Y cuando una familia de escasos recursos intenta, contra viento y marea, contra los imperativos económicos del tiempo, ser fiel a la tradición, se ve obligada a forzar el proceso, a precipitar los acontencimientos; es decir, el matrimonio de los hijos. Entonces cae en el "quiero y no puedo". Entonces se produce lo ridículo, lo exorbitado, lo cursi. Poco después, las hijas de familia comienzan tímidamente a trabajar en secreto. Hacen flores artificiales, puntillos, labores. Pero con el mayor misterio, para que no padezca mengua de honra de la casa. Luego, como síntoma precursor de su próxima liberación, se decidirón a "salir a la calle". Más tarde, ya en pleno siglo XX, emprenderán resueltamente la lucha por la vida. Y en lo sucesivo, sus usos y costumbres dejarán de ser materia de humor, pues ya no habrá diferencia entre lo que pretenden y lo que son... 


\section{c) Autor}

Jorge Miota ha pasado a ser referencia ineludible cuando se trata de autoría literaria, aunque las circunstancias específicas del hallazgo se hallen enrarecidas por la vacilación y por la duda.

José Gálvez, a quien citaremos nuevamente, le recuerda como primigenio introductor, en la conversación llevada a cabo con el periodista Labrador Ruiz.

- Y eso de Jorge Miota es cierto? -digo por romper el silencio-. Me refiero a la invención de la palabra huachafa, ese peruanismo tan agudo.

-Mire usted -me dice el doctor Gálvez-; Miota por lo menos es el introductor de su valencia de cursi y estrafalario...

Ezequiel Balarezo Pinillos, "Gastón Roger", entrega en su testimonio una nota de imprecisión y de leyenda.

Dicen que de labios de Jorge Miota nació el vocablo. Si no fuera cierto debiera serlo. Aquel fino cuentista, enamorado de Oriente, aquel gran limeño de frente luminosa, cabellera y mostachos erectos y ojos de fiera; aquel asiduo lector de Huysmans y Mendes, aquel importador enardecido, busca. ba la contemplación del crepúsculo mirando con los delirios de su mente extraviada el vuelo de lejanos turpiales y los minaretes de remotos castillos (y todo esto desde los carros del tranvía urbano, entonces halados por postillones negritos y sudorosos), era un conversaddri formidable...

Vaguedad más o menos similar a la apreciación de "Cabotín".

¿Quién inventó este modismo, cuya difusión es creciente? Alguien me ha asegurado que fue Jorge Miota. En todo caso, el vocablo ha quedado completamente incorporado a nuestro léxico.

En 1943, José Gálvez sostiene y aclara.

Y Jorge Miota introductor del término huachafita con diferente sentido al colombiano.

José Chioino, "Juan de Ega", en su extenso artículo "La huachafita", afirma con pretensión documentada:

De acreditadas opiniones de la época hemos obtenido que el del hallazgo fue el escritor Jorge Miota. 
"Juan Apapucio Corrales", Clemente Palma, separa la voz de la jerigonza perdularia y llega a la adjudicación a través de terceras personas.

Huachafa, esta palabra no es del argot sino un modismo inventado hace treinta años, según se asegura, por el notable escritor y causeur Jorge Miota, gran observador de las costumbres y psicología de la clase media.

Rubén Sueldo Guevara en Narradores cuzqueños, establece enfática paternidad.

Es el creador del más expresivo peruanismo: huachafa.

Sin embargo, en la obra Peruanismos, el anterior aserto no es lo definitivo, porque como apunta Martha Hildebrandt.

A propósito del término huachafo, se discute la paternidad del mismo por parte de Jorge Miota.

\section{d) Teoría}

Hasta el presente, muchos escritores han tratado de hallar la esencia de la voz entre sus pliegues secretos.

A juicio de José Chioino.

La huachafería es precisamente el afón de no parecerlo, el querer ser elegante a toda costa. És la sortija de la corbata, el sombrero, es la Mhànera de hablars conque ciertas personas quieren hacerse interesantes. Porque entre la originalidad que es una elegancia innata, y la huachafería que está en andar a puñadas con la originalidad para lograrla, hay un paso...

A pesar de que en el mismo texto observa la imprecisión en la que se ha caído.

Desgraciadamente el término se va haciendo vago, se le emplea indistintamente para significar condición social, mal gusto o simplemente para ejercitar venganza contra una rival. En aquello de emplear, por extensión, el término huachafa para designar a todas las hijas del que no posee una renta de mil libras anuales y no tienen su domicilio dentro de ciertos barrios de la capital, hay un acierto en la mayoría de los casos, pero también hoy una injusticia y un abuso del término. El mal gusto no tiene que ser dependiente de la fortuna. Que la mayoría de los casos de huachafería se da entre personas de escasos recursos, no es una razón para el acaparamiento del título. 
En la nota introductoria a "Breves apuntes para el manual del perfecto huachafo", de Fernando Escobar, Clemente Palma reconoce una nueva dimensión.

La "huachafería" es al presente una institución, una gran familia nacional perfectamente caracterizada y cuyas relaciones, gustos, y demás particularidades pueden catalogarse andando el tiempo para satisfacción de la historia patria.

Abelardo Gamarra señala una situación infortunada.

En el fondo de la huachafería hay una infelicidad material o espiritual, que merece compadecerse.

Aunque la diversidad de actividades sociales en la urbe, posibilítale otras comprobaciones.

En los paseos públicos, en los bailes caseros y hasta en los de Sáenz Peña, se ve la huachafería, como que todo lo que sale del tomo general de un acto; todo lo que desafina en una orquesta, o chilla en un color, o disuena es huachafo.

"Gastón Roger", antes de teorizar advierte:

Establezcamos una premisa fundamental: la pobreza no es huachafería. Otra premisa: la huachafería comprende los dos géneros gramóticales

Hay niñas ricas y hombres públicos que son ostentosamente huachafos. Concreción de la inteligencia, del gusto, del instinto y de la costumbre, la huachafería se transparenta en la palabra, en el hábito, en el gesto, en el traje, en la lectura, en la comida, en el saludo. Sello inexorable del destino, se nace huachafo como se nace indigno o se nace cobarde. La educación atenúa, pero no vence las indisciplinas morales o espirituales.

Como consecuencia, hay grandes huachaferías colectivas; una huachafería religiosa, la procesión del Señor de los Milagros; una huachafería teatral, la opereta; una huachafería legendaria, el romanticismo de la Perricholi; una huachafería castiza, los portales a las 7 de la noche.

Críticos como Jorge Patrón en "Aspectos de la huachafería", prefieren para el caso no sólo los carriles axiológicos.

Es muy corriente en confundir la huachafería con el mal gusto. Se supone que lo huachafo es lo estéticamente malo. Sin embargo, aunque el mal gusto informa en la mayoría de 
los casos el fenómeno huachafo, no por esto en su cualidad esencial. Lo huachafo tiene un campo de acción muy vasto, no está limitado solamente a lo estético. Lo huachafo existe en todos los sectores de la vida; una novela, un edificio, un gesto heroico, un saludo callejero. No es un fenómeno de puro sentido artístico, sino más bien es cuestión de desadaptación.

Desajuste que en su opinión compromete temporalidad y circunstancia:

La desadaptación en este caso puede ser doble o desadaptación al tiempo o desadaptación al medio.

Un caso típico de desadaptación al momento es el de la moda. Lo pasado de moda es siempre huachafo, es algo que cayó en desuso, estadios ya superados, regresar a ellos es renunciar al momento, a la época actual ... La moda pudo haber sido estéticamente superior a la nuestra, sin embargo para nosotros resulta fea y huachafa, porque rompe nuestro equilibrio y no se adapta a las normas acostumbradas.

El nuevo rico, el arribista, es el caso del desadaptado al medio. Generalmente burgúeses que han elaborado su fortuna paso a paso, y que repentinamente abandonan su mundo para escalar esferas sociales superiores, se encuentran en ellos desorientados, no atinan a actuar conforme a las normas que rigen en ese medio, en éste: nuevo mundo. Tratan de imitarlos, pero como esta imitación es torpe y claramente se ve en ella lo artificial, surge el fenómeno de lo huachafo. No porque ellos tengan un mal gusto o porque las clases superiores estén dotadas de un sentido estético más afinado, sino únicamente por que no actúan dentro de su propio medio.

No obstante, el mismo autor, en busca de otra explicación, también se acoge al psicoanálisis.

Freud sostiene la teoría de que en el individuo existe un sentido del disparate, es decir una tendencia a liberarse del círculo de hierro, de la razón, cuantas veces se debilita la censura. Es quizás, en este sentido del disparate, donde puede hallarse la génesis de la huachafería, como una liberación a los preceptos estéticos, a la censura artística. La huachafería se convierte entonces en una rebelión y a la vez en una liberación contra el orden establecido.

En Lima la horrible (1964), Sebastión Salazar Bondy denuncia el contenido lexical como estrategia y barrera del sistema.

La norma manda comportarse medida, respetuosamente, 
sin exageraciones exteriores, sin saltar las etapas en la promoción que, a falta de linaje, se ha hecho imperativo cumplir. Y tal cual para la opinión mordaz ha sido establecido el valladar de la lisura, para la actuación pública ha sido trazada una frontera artificial cuyo franqueo arroja al individuo o el grupo en la huachafería.

Lo que importaría consecuencias evidentes, muy notorias en el desembozado desdén de la oligarquía intelectual, como lo señala ya V. R. Haya de la Torre en 1925, en "La nueva y la vieja generación de intelectuales en el Perú".

En torno de Palma se agruparon los señoritos de la intelectualidad aristocrática limeña: con [González] Prada se fueron los provincianos, los modestos y los huachafos como les llaman los otros, dejando resbalar este vocablo por sobre cualquiera de los hombros.

José Chioino supone, apoyándose en una fonética sui generis, un corrosivo secreto.

¡Qué huachafería! Porque hay algo en la eufonía del término que parece indicar el contenido; es una de esas palabras que parecen que tuvieran conciencia del rol que desempeñan en el vocabulario. Cuando oímos decir en un teatro, en el jirón la palabra que siempre se pronuncia despectivamente como con indignación, se nos imagina que algo ha caído sobre la víctima a quien iba dirigida. La terrible palabra vendrá a nuestra boca, y por sugestión inuestros ojos la seguirán viendo huachafa, por más que haya corregido su indumentaria.

\section{C) Apariencia}

No cabe duda que en la palabra existe un trasfondo crematístico, implicancia entrevista por más de un escritor atento a la peripecia del vocablo.

La pobreza de espíritu y la pobreza de bolsillo, son las que engendran las huachafas. El deseo de aparentar y de no querer ser menos que nadie hacen que las gentes sean huachafas -comentó Abelardo Gamarra "El Tunante" en Rasgos de pluma-.

No en vano la censura de "Balduque", culmina en una realidad que logra comprobar.

Predicando en el desierto/ Tú eres, como muchas/ hua- 
chafas de Lima,/ que conocen muy poco/ por echarse encima/ encajes y blondas/ y estar elegantes/, y comprar vestidos,/ cintajos y guantes./ Cuántas blondas./ Huachafita./ Y cuánta hambre/...

Existe otro perfil proletario que pertenece al mismo autor.

Tras un flete huachafoso/ mal trajeado por hermoso,/ me he pasado siete días/ en continuas correrías/ Tras un flete/ es donaire que promete./ Y aunque vive en la Pampilla/ $\mathrm{y}$ es humilde modistilla.

Similitud en ocupación, a su congénere poético del Plata que fuera creado por Carriego: La costurerita que dio aquel mal paso.../ y lo peor de todo, sin necesidad-/ con el sinvergüenza que no la hizo caso/ después... - -según dicen en la vecindad-.

Fernando Escobar en "Breves apuntes para el manual del perfecto huachafo", entre burlas y veras nos remite a concretas estrecheces.

-Estrena- quién lo dudal - el 28 de julio y Año Nuevo, y en esos días el calzado nuevo.

Los guantes hân de ser borlón [...] son lavables y parecen gamuza a la distancia.

O cuando trấa laliáéxico. de Letras

De gastar sortija, ésta ha de llevar-condición sine qua non- las palabras tiernísimas de "mizpah" o "amistad" y en los relojes prefiere el "Waltham" dos picos, y si las económicas le permitieran comprar uno de oro, a plazos, lo usaría con su funda de franela.

Rosé Bercis, reprueba ignorancias -El Comercio, Lima, 28 de julio de 1953-, en "Teoría y práctica de la elegancia. ¿Qué es la huachafería en el vestir?".

Tampoco diferencia los toilettes adecuados para las ocasiones determinadas y es así como muchas veces la detectamos en una mañana de playa o en algún almuerzo campestre ataviada con llamativo vestido de raso, encaje, terciopelo - brocados. Para ellas no evolucionan la moda en el peinado ni en el maquillaje, se apartan de todo lo que es naturalidad y van en completo desacuerdo con la línea moderna... En síntesis, la huachafería es la negación de la elegancia. 
Al predicar, refinamiento $\mathrm{y}$ cachet en una realidad con un analfabetismo del $60 \%$ y una mortalidad en la niñez del 90 por mil, ejemplificaba con largueza, hasta qué punto, cómo una clase aristocrática llena de frivolidad y estolidez, hacía tiempo que había perdido el ritmo de la historia. Pero a la vez se comprueba que cuando la burguesía, irónicamente denigraba como impúdicas las reproducciones de una moda que ella misma la imponía, su contradicción graficaba también -en calamitosos alegatos- el poder y la ventaja aristocrática frente a una clase desvalida. Todo ello, eso sí, dicho con el aplomo de un dominio largamente ejercitado.

\section{f) Arquetipo}

A Fausto Gastañeta, animador de los más puros guiñoles huachafos pertenece este relieve.

Etelvina por supuesto de noche: una manta de la vieja, con una media luna de cartón, sobre el pecho y en la frente la estrella que guiaba a los Reyes Magos, en el último nacimiento que armaron en Lima. Qué noche, querido lector, una noche sin par, por la larga y de recepción de huachafas, por lo ridícula. La segunda gota fue Zoraida: de Manola cómo no. Si a las huachafas les da siempre por escoger disfraces graciosos de españolas y luego resultan perros rabiosos, porque se impone matarlas. Tercera gota, la vieja, de nene Ohl. Si la ven ustedes con falda corta, medias medias, alpargatas, gorritos con blonda y un casaquin, entre celeste $y$ menos celeste, y con su sonajita llena de frijoles; ćuyob mangoesta el residuo del palo de un plumero.

En el hebdomadario modernista Actualidades, Leonidas Yerovi trazó una caricatura festiva de la huachafita y el huachafón.

Tipos: Frágil, menuda agraciada,/ no exenta de gentile$\mathrm{za}, /$ de listón en la cabeza/ y de faz enharinada; que en la tieza falda alzada, / luciendo el pie bien ceñido,/ y dirigiendo al descuido/ cada mirada que inquieta/ va de retreta en retreta/ a la pesca de un marido/ que no halla la pobrecita.... Huachafita.

De clásicos pabellones,/ de mirada torpe y dura,/ de risible catadura/ y de holgados pantalones;/ rostro que otorga perdones/ y su cuerpo mal entallado,/ y ademán impertinente, como advirtiendo a la gente/ que atraviesa por su lado;/ "temedme soi un matón..." Huachafón.

En opinión de don Abelardo Gamarra. 
Una huachafa es una mujer adefesio, o como dicen ellas, es una adefesiera. Hay huachafas de forma; otras de fondo $y$ las de remate, son las de forma y fondo. La que en tiempo de verano, y cuando más se suda, sale con traje de terciopelo. sombrero de castor, guantes de lana y sobretodo, es una huachafa de forma, o mejor dicho, una huachafa en toda forma. La que en la conversación mete cuchara y da explicaciones sobre la trisección del ángulo u otra materia en la que está tapada, $\mathrm{y}$ dice disparate $\mathrm{y}$ medio $\mathrm{y}$ latea a rosa $\mathrm{y}$ belloso, es una huachafa de fondo. Y la que viste adefesieramente, usa modales disforzados, baila dando brinquitos $\mathrm{y}$ habla disparates, es una huachafa de tomo y lomo. La huachafa es un costeo.

El documentado compendio "Breves apuntes para el manual del perfecto huachafo" (1917), hizo referencia a la terminología del huachafo.

-Cuando los asuntos amatorios del huachafo marchan viento en popa, les dice a los amigos: "estoy pura flor".

- Si pretenden tomarle el pelo, se defiende diciendo: "- eso es que me lo digas, pero que me carambolees, ¿cuóndo?"

- Y como colmo de galantería, en un fá a las 5 y media a.m. no será raro que al oído de su compañera, si ésta le hizo una promesa, deslice estas frases: "para qué más vida... cuando se recibe una satisfacción".

\section{A su atavío.}

\section{"Jorge Puccinelli Converso"}

Las solapas de la americana se las ajusta con "barbas" o "resortes". Gusta de la boquilla de "cerezo" o de las manecillas doradas si resulta fumados. En las corbatas es caprichosísimo. Prefiere las de resorte de lacito a colores vivos en las cuales usa "imperdible" de dublé.

A sus flirts.

A la enamorada la llama su "tormento" y "dulce prenda". En amores es ventanero, hace amistad con el guardia, nunca se declara sino por carta, y conoce el lenguaje de las flores al dedillo. Naturalmente siempre usa clavel rojo: "Amor ardiente".

Incluso, remitiéndonos en sus peripecias a un detallado conocimiento de las esferas sociales de aquel tiempo. 
Se atufa si no le escobillon el saco. Y no da propinas... "son tonterías" de los entalladitos del Palé... Come con ila servilleta amarrada al cogote sudoroso para defender así:la camisa. (En este procedimiento se parece a la mar de diputados que manyan en el "Berlín" o en el "Estrasburgo". Y se molesta que lo puedan llamar "huachafo"... ¡Huachafo! él, huachafo un hombre que usa crema de almendras y que guarda los sonetos de Pasquale.

Creatura que inspira a Angela Ramos una de las páginas más frescas y pimpantes de la literatura peruana.

La huachafería tiene también tres prototipos bien definidos: la huachafa, la huachafosa y la huachafita. Los tres se diferencian sustancialmente en edad (sobre todo). La huachafa puede ser joven o jamona como la huachafosa; pero la huachafita es incuestionablemente polla. Además, la huachafita es siempre o casi siempre bonita.

La huachafita es la que más se aproxima a las niñas bien, razón por la cual muchas niñas bien también se parecen a las huachafas [...]. La huachafa es insustancial, la huachafosa bestial, la huachafita natural (como el agua de Viso). La primera es la víctima de los bigotes; la segunda de los galones; la tercera del Chevrolet.

Presentando algunas veces antológicos fragmentos:

A la huachafa le gusta que le digan, a la huachafosa que la sigan y a la huachafita que la persigan. La huachafa siente; la huachafośa se resiente y l la hưachafita consiente. La huachafa tiene su flete, la huachafosa su peor es nada, la huachafita su adorado tormento. La huachafa es querendona, la huachafosa besucona, la huachafita reílona...

\section{g) De los diversos calificativos}

El vocablo una vez localizado prestó matices sugestivas en el habla, los cuales -oralidad aparte- a su turno se pueden comprobar en el cuento, la novela, el periodismo y el ensayo.

Singulariza el carácter sentimental de Blanca María, cóndido y voluble personaje de Abraham Valdelomar en "Mi amigo tenía frío y yo tenía un abrigo cáscara de nuez".

Oh amor temprano, oh zambita ingenua, anémica y pecosa que eras para mí, bella y perfecta como la Victoria de Samotracia, oh Blanca María, amor primerizo, oh romántica huachafa... 
Trasladado y bajo el influjo de José Diez-Canseco a otras latitudes por Benjamín Carrión en la obra San Miguel de Unamuno, coopera en la plasmación de insólitas metáforas.

Don Goyo, novela grande, con la epopeya ancha y fecunda, corruptora y mortífera a la vez, de la tierra caliente nuestra que, siendo tan caliente como la tuya-porque es la misma tierra- tiene además la acechanza asesina del mangle, cuyas raíces son un encubrimiento, una complicidad y una emboscada; la caoba, la tagua, toda la enredadora lujuria del bejuco, el inútil abanicar de las palmeras -máxima huachafería el trópico-, y la hostilidad segura del espino.

Reseña virtudes del autor de Duque.

Su sabiduría de vihuela y caión, de sanmigueles y piuranos y huachafería truculenta, no ha sido adquirida para escribirla después en los papeles. José goza en el canto peruano como en la jarana de su tierra, en entregamiento espontáneo, en buena y sabrosa realidad cotidiana, $\sin$ fin $\mathrm{y}$ sin propósitos ulteriores de aprovechamiento literario o documentación.

Y aún subraya femeninas preferencias.

El abrazo de esa mulata de Piura o del Callao, obtenido tras obstinada faeng de canto, pisco y zapateo, no lo contamina él jamás con la química cerebral de una preparación para escribiru JoYgentrecsácrifican el/logro de una aventura de esas de especie y vals huachafo, y el éxito literario de El Gaviota, José no habría vacilado jamás... Nos habríamos quedado sin leer El Gaviota.

Clemente Palma lo incluye en su glosario peruanista y le cede intenciones pendencieras en "Correo Franco" de la revista Variedades.

Este último verso se lo ha inspirado a usted la canción de la "Carmela" tan popular entre las huachafas y que dice: "Dios me ha negado de tu amor la palma..."

Descubre en Duque, limitaciones en capillas literarias.

"Carlos tenía que medir sus palabras. Pensó: felizmente no está aquí Teddy: metería la pata. Hablaban de una próxima conferencia en "Entre Nous". Carlos esbozó un chiste malévolo: 
- Ah, Entre Nous! Las señoras van allá a pensar, como irían a hacer pantallas ... o calcetas...

- ¿Cree Usted?

-Si, Lola. Allá no tienen acceso las "huachafas"...

La Pomar no respondió. Se atufó y cambió la charla...

Relaciona criollismo y peruanismo, según se colije de un reportaje de Luis Alberto Sánchez a Alfredo González Prada.

El criollismo era lo "huachafoso"... Lo europeo; lo elegante, lo snob. Decir que aquello era absurdo, sería absurdo!. las tendencias literarias de un instante, los movimientos literarios no son absurdos o no existen, simplemente; son un hecho. Y el "hecho" en el colonidismo fue ese espíritu europeízante, de espalda a la realidad peruana. Más tarde, Mariátegui (que no perteneció a nuestro grupo, pero que espiritualmente -en 1915 y 16 - estaba asimilado a él) sintió la necesidad de reaccionar contra ese exclusivismo, y con su lema de "peruanicemos el Perú", marcó la reacción contra los excesos del colonidismo. Si hubiéramos llegado a fundar una "escuela" u oficializar la existencia de nuestro grupo, y a la manera de las capillas literarias de Europa, hubiésemos lanzado nuestro "manifiesto" de seguro que uno de nuestros lemas habría sido "desperuanícemos" el Perú... "Deshuachaficemos" el Perú. tórica.

Con Teófilo Castillo cobra esencialidad dentro de la crítica pic-

\section{"Jorge Puccinelli Converso"}

Challe, es sabido, constituye una rareza entre los dibujantes nativos y de su género. No necesita apuntador para el concepto. Hace el mismo la letra de sus planas y tanto la línea como el verbo fluyen de su cerebro y lápiz de la manera más fácil, espontánea. Todos los temas le resultan apropiables, aún los mós complejos. Su género predilecto es el costumbrista, el de la vida de la clase media limeña, su pretenciosismo, huachafeo pintoresco, sus estridencias en el vestir, noncuranzas por la higiene, su indisciplina incurable, sus mestizajes híbridos, espeluznantes algunos.

Con el mismo crítico en "José María Eguren", amplía horizontes idiomáticos hacia espacios lusitanos, al observar la arquitectura de la iglesia de Barranco.

Mientras Alcántara toca el timbre y contempla ansioso una apariencia de beldad femenina que fugaz pasa, yo observo el singular estilo cacofónico - paquidérmico de la igle- 
sia vecina- ¿Qué portugués coluso huachafáite, habrá sido el autor de este insigne mamarracho arquitectural? -pienso.

A la vez que en superlativo acento grafica desdeñoso uno de los lugares más castizos de Madrid.

Con el mismo criterio estando ya en España, no fue Madrid, Barcelona, ni Sevilla que más provocaron mi fervor. En Madrid sentía horror por su huachafosísima Puerta del Sol, hervidero de tíos $\mathrm{Y}$ tías, de chulos $\mathrm{Y}$ cómicos sin contrata.

Extiende imagen adverbial en el diario La Prensa, en una entrevista de Del Valle.

A la argentina iche! Esmerada y elegantemente empaquetados en vistosas cajetillas nos enseñó el señor Villarán unos cigarrillos "Estanco" que llevaba la consabida leyenda en letras huachafescamente doradas.

Un mes antes del primer artículo que se tenga noticia - 14 de marzo de 1903- sobre la naturaleza de la voz y, posiblemente, cogida de la parla impuesta por el atrabiliario Jorge Miota en el corrillo de la revista Actualidades se inserta, todavía con una grafía vacilante o colombiana en el mismo hebdomadario a través de "Exitos", un relato de Augusto Salazar.

En otra ocasión, y estando de tertulia en una casa de lamparín, habitadáp por muy simpáticas ys honradas chicas del entretenido gremio de guachafas se me invitó a jugar prendas.

Con la modestia qué me caracteriza"debo aclarar aquí, en honor de tan simpática familia, que en la casa se me tenía y presentaba como un distinguido joven intelectual y se me conocía por "el periodista".

En Hispanoamérica, donde la literatura es en algún aspecto un instrumento de denuncia, el vocablo no podía estar alejado del mundo del panfleto y la contienda. El otro Caín, de Manuel $A$. Bedoya así lo certifica; en la caracterización que hace el autor sobre el estilo del decano de la prensa nacional.

El murciélago de la Rifa tendió su ala musilaginosa sobre lo que pasaba, y en las primeras columnas de sus ediciones riseaba esa su parda prosa blanducha consagrada a sucesos internacionales. Aquella mentalidad crepuscular de literatura catarrosa, llena de arrugas intelectuales, sin vuelo alto, sin noble claridad de conceptos, siempre con el adjetivo huachafo agazapándose detrás de prejuicios mediocres de refranejos de sacristán. 
Alberto Hidalgo le acrecentó pintoresca vitalidad, bien en la literatura del desprecio.

El señor Sassone puede ser muy elegante, muy buen mozo, muy bohemio; puede tener los ojos más encantadores que haya concebido cualquier huachafa de Lima; puede ser el amigo más leal que haya imaginado Vallecito; puede ser todo eso y más si se quiere; pero no escritor. ¡No por Diosl

En la befa de un lenguaje adocenado a propósito de José Gabriel Cosio.

Este se parece a Belaunde: "Cuando almorcé con Bergson", "mi amigo el rector de la universidad de Cambridge", etc. Como huachafo, tampoco tiene par en el mundo: "Vengo atraído por el reverbero mágico del arte", " a escalar el último peldaño de esta bella Facultad que tiene todos los atractivos del encanto y todas las bellezas del pensil", "en esta Facultad de Letras que me ciega con sus resplandores, que me deslumbra con sus rayos, como un sol de fuego que incendia las nubes de púrpura en el espacio inconmensurable". Así comienza una tesis suya que se moteja [EI] americanismo literario y que debería llamarse Mariconería literaria. radojas.

O en la cóustica infidelidad al poeta de La torre de las pa-

A propósito de Anunciación, con el objeto de solicitar colaboración de "algunos escritores nacionhelès, acordamos enviarles una carta de cuya redacción encargamos a César $A$. Rodríguez. Esa carta no se llegó a mandar en vista de lo huachafoso, abigarrado, necio, inconexo, dislocado y arlequinesco de su estilo, como es todo lo que escribe Rodríguez. Para que el lector sonría un momento, la reproduzco. Hela aquí:

\section{Muy señor nuestro:}

Para llevar el bagaje de nuestras ilusiones por las calles de este pueblo enfermo, hemos formado un cenáculo donde nuestros corazones serán como llamas convergentes de un turíbulo ofrecido en holocausto ante el platónico festín de las estrellas.

Nuestra divisa será un orgulloso gesto de teatralidad bohémica y una epigramática sensación de vida que juntara nuestras trasnochadas melenas cuando estáticos quedemos mirando el cielo a caza de consonantes fugitivos, que a modo

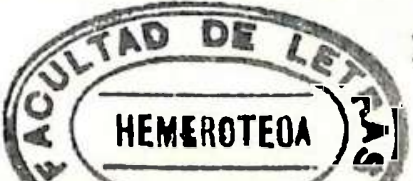


de golondrinas becquerianas se difunden en las lontananzas vacías del infinito...

En la novela Los cachorros, de Mario Vargas Llosa, asume clara delimitación del territorio social capitalino.

Pero él no quería tener enamorada y ponía cara de forajido, prefiero mi libertad y de conquistador, solterito se estaba mejor. ¿Tu libertad para irse de plancito?, y Pusy con huachafitas?

En lo que incumbe a modos de ser de lo criollo, pertenece a José Carlos Mariátegui la siguiente observación de nuestro particular temperamento.

El humorismo de Valdelomar se cebaba donosamente en las disonancias mestizas o huachafas. Una tarde en el Palais Concert, Valdelomar me dijo: "Mariátegui, a la leve y fina libélula, motejan aquí chupajeringa". Yo, tan decadente como él entonces, lo excité a reivindicar los nobles y ofendidos fueros de la libélula.

Que el léxico "colónida" fue permeable al nuevo término, lo mismo que la agrupación que seguía a Abraham Valdelomar, fuese notable difusora lo confirma un artículo festivo del semanario Don Martes (1918), en torno al lenguaje de Mariátegui.

Habla Juan Croniqueur? "Este-Martínez Sierra tiene una alma nítida Jo diáfanaccomb eb argua potable. Yo le odio. Yo no le quiero. Los intérpretes están muy mal de "voces". Martínez Sierra ha escrito otras obras como Amanecer. Otras obras nítidas y diáfanas. Otras obras inconexas, inconsistentes, delezriables, delicuescentes y huachafas. Los protagonistas de Martínez Sierra de ser limeños vivirían Abajo el Puente. Carmen es del Chirimoyo, va los domingos a la calle Nueva a ver pasar a la gente de los toros. El millonario es más bruto que el diputado Vivanco. Odio a Martínez Sierra. Odio a Amanecer. Odio las malas noches. Yo vivo en Magdalena.

No solamente la palabra se instala en la voz cantante de la narrativa actual - la de Vargas Llosa, Bryce y José Bravo- sino inclusive en los desaliños y devaneos decadentes, a lo Felipe Trigo Y "El caballero audaz", caso de Era romántica de Carlos Trou Stevenson, "colónida" allegado y confeso diletante.

Transcurridos algunos días me hice presentar a Susana por mi amigo Juan, un muchacho inteligente, algo desencan- 
tado de la vida, quien años atrás se había exhibido como poeta selecto, escribiendo versos que fueron bien acogidos entre los pollos románticos y sentimentales; pero a quien un más detenido examen de la idiosincrasia humana, le convenció que mejor que cantarle dulzonas ternezas a Madama la Luna, para deleite de una que otra huachafita enamorada de lo ideal, era revelarse un hombre práctico, producto singular $\mathrm{y}$ altamente representativo de nuestro prosaico siglo.

En última instancia si es verdad como denuncia un personaje de Augusto Roa Bastos, en el sentido de que el mundo está envenenado por las palabras; con respecto al vocablo que establece Jorge Miota, cabe suponer que de réproba malandanza se ha encargado no sólo una vocación satírica que subyace, sino también todo un retórico andamiaje de una cultura dominante que la incautó para su uso, al mirar con desdén peyorativo a una clase que imprecisa no aceptaba su postergación y su destino; inútil resistencia, porque a la postre la pequeña clase media se haría receptora de la invectiva lexical, tal vez porque ella era "madre ubérrima y propicia a todas las insensateces", como la llamó en alguna crónica César Falcón desde Madrid.

\section{VIDA}

\section{I) "el penoso debetlcomo gefecque fuitras}

Jorge Miota, con propiedad Jorge Miota González, nació en la ciudad de Apurímac en 1871, su padre fue don Manuel Miota, un:do en matrimonio con doña Serafina González y, muerto heroicamente en Miraflores, "sangrienta batalla donde la derrota humilló a los peruanos", como define la debacle Pedro Dávalos y Lisson, en esa especie de autobiografía titulada Cómo hice fortuna.

El nombre y grado de su progenitor se suma a la nómina de los muertos ilustres que se adjunta en el lacónico parte que envía don Adolfo Silva al capitán de navío Aurelio García y García, Secretario General de S. E. el Jefe de la república, según se consigna en la Colección Ahumada, Guerra del Pacífico.

"Señor Secretario: Un tanto restablecido de la profunda impresión que en mi espíritu produjeron los desastres experimentados por nuestras armas, en los nefastos días 13 i 15 del corriente, así como la herida que recibiera en la tarde del último, me apresuré a cumplir con el penoso deber como jefe que fui del Estado Mayor General de los Ejércitos hasta esa misma tarde...". Entre los altos mandos y oficiales que habían sucumbido en la contienda se en- 
contraban entre otros el coronel don Pablo Arguedas, Comandante General de la 2da. División del Norte, capitán de navio don Juan M. Fanning, Primer Jefe del Guanición de Marina, teniente coronel don Manuel Miota del estado Mayor General y los capitanes Natalio Sánchez y Manuel Guerra...

El apellido Miota es de ascendencia hispánica, habiendo sido el primero en poner pie en tierra peruana el vizcaíno don Juan José Miota, más tarde acaudalado propietario de la hacienda "Huatquiña" y "tronco del apellido en América", como Jorge Miota manifestara alguna vez sobre su ancestro, dando así acabamiento a la afirmación que solía echar a volar a propósito de ranciedades y abolengos: "El Perú todo, es un viejo manuscrito por el que reaparece, a pesar de la moderna cubierta de su empaste, la rúbrica castellana de un antepasado". Precisamente un descendiente de don Juan José, Fermín, será con sli primo Fernando, recién llegado de Vizcaya, singular compañero de viaje de la Paria en el largo viaje desde Burdeos al Perú.

Fermín Miota había sido enviado a estudiar por sus padres a París cuando tenía dieciséis años de edad; nueve años después haría su retorno.

Sobre el abuelo paterno de Jorge Miota, Flora Tristán en Peregrinaciones de una paria, recordará las glusiones de monsieur David a sus "susceptibilidades peruanas", y ella misma como a un personaje "habituado a todas las dulzuras de París".

II) "de carácter interdepartamental"

Abancay ("el que lleva"), es en la actualidad una provincia del departamentodee Apurímac,i delacuerdo a la ley que se promulgara en 1873 -dos años después que naciera en ella Jorge Miota-, la misma que modificaba la del 19 de noviembre de 1839 que creaba la provincia de Abancay como integrante del departamento del Cusco, hecho que ha dado motivo tal vez para que se afirme en algunas ocasiones que Miota había nacido en la ciudad del Cusco. La duda en la materia quedó bien esclarecida en un artículo enviado a Clemente Palma y que apareciera en Prisma, bajo el epígrafe de Una visita al "Sacsahuamán": "En Apurímac nací -afirma-, así es que de carácter interdepartamental con ascendientes en el Cusco y habiendo vivido en Lima, toléraseme ciertas intemperancias de renegado".

\section{III) "mi memoria de ex-guadalupano"}

A los pocos años de nacer el primogénito, el entonces capitán Miota obtiene su traslado de Abancay a la ciudad de Lima, radicándose en Barranco. Cuatro años después de residir en la capital, se producen las primeras hostilidades entre el Perú y la re- 
pública de Chile, que van a ocasionar la llamada Guerra del Pacífico.

La muerte del padre en el último reducto de Miraflores, el 15 de enero de 1881, dejará al pequeño Jorge, que apenas cuenta con diez años de edad y a doña Serafina González en muy precarias condiciones económicas, situación que recuerda la madre en una carta enviada al diario de Baquíjano en 1914 a propósito del juicio que inicia "por secuestración".

Sin embargo, y a pesar de una vida de necesidad y de zozobra, educa a su hijo en el Colegio Guadalupe, cuyo elenco profesoral lo integran Eusebio Rodríguez, Cesáreo Chacaltana, Manuel Marcos y don Artidoro García Godos. De los cursos que se imparten, le atraen al futuro escritor, la literatura y el francés.

De su época guadalupana evoca su renuencia al estudio del pasado en el texto Historia del Perú, del circunspecto don Manuel Marcos Salazar, cuya ampulosidad oratoria será el blanco de sus pullas, sobre todo cuando el engolado profesor tilda de "capitolio" a Sacsahuamán, "ombligo" al Cusco y "empíreo", para señalar el límite natural de las fortalezas y palacios; advirtiéndose en ello, una crítica al lenguaje adocenado y al uso, que presagia a un definido modernista.

IV) "tiene el honor de presentarle al literato peruano Dr. Jorge Miota" F. G. C.

Concluidos sus estudios en el Colegio Guadalupe, el joven Miota se echa "en busca de destino". Es la postguerra del Pacífico, y el Perú atraviesa una etapa- de-penuria y estrechez; es una situación en la que suelen juntarses poin igüal, según el, testimonio de Dávalos y Lisson: "una miseria espantosa" en las masas, "una degradación moral producida por la derrota" y "una avaricia que duIa hasta el presente".

No obstante las oscuras perspectivas, la pasada amistad entre don Nicolás de Piérola y el extinto teniente coronel Miota, renace en la posibilidad de una apartada secretaría burocrática.

Su confesión reiterativa: "De costeño tengo el soroche serrano, y de serrano la decidida afición a cabalgar", se materializa así en un viaje a una lejana cuenca apurimeña. En sus valijas lleva un nutrido equipaje literario: Balzac, Poe, Maupassant, Zola, Goncourt, Huysmans...

Allí, en ambiente de manigua y soledad, mezclará también extravagancias y manías: se viste de tirolés e ingresará a su oficina en la grupa de un jamelgo; mas, la calentura palúdica no respetará a los paisanos, y el estrambótico secretario prefectural, tendrá que retornar a Lima en busca de cura y de reposo; pero, escritor de varios rumbos, emprende de inmediato la ruta 
inversa a la de Carrió de la Vandera, "El lazarillo de ciegos caminantes", llegando en 1900 a la Argentina, a donde habían ya arribado muchos compatriotas, huyendo de la violencia impuesta por la ocupación, como corolario de la Guerra del Pacífico. Meses después atraviesa El Plata a bordo del "Venus" con dirección a la república oriental, que de veras le apasiona y donde encuentra un mundo hospitalario; de ello deja testimonio en "Impresiones de Montevideo".

Del Paraguay retorna al Perú, para empezar intensa actividad en periódicos y revistas, hasta que hacia 1911 su figura se esfuma de los medios literarios, para reaparecer inesperadamente en Fran. cia, con una decidida intención de radicarse; sus condiciones de vida han debido ser estrechas y aguijoneado ya por una locura a ojos vistas galopante, pero, seguramente acicateado y deslumbrado por París, como tantos modernistas.

Un día tocará las puertas de la Legación Peruana, buscando una tarjeta de recomendación para Darío, poeta siempre abierto $\alpha$ inquietudes y angustias de bisoños e ilusos literatos llegados a París; en cierto modo con Miota se reeditaba el caso del infortunado Lora y Lora. Al respecto, un parágrafo de una epístola del autor de Anunciación a Darío es una prueba de la brega descarnada por sobrevivir en esas latitudes: "Naturalmente, yo no puedo exigir a Ud. nada porque, si es verdad que Ud. me garantizó una mensualidad, a cambio de pequeños servicios que pudiera prestar a Ud. aquí i si es verdad que en América, no obstante lo malo de mi situación, la lucha en otros órdenes de la vida no es tan cruel como acá.

Francisco García Calderón, antiguo-Colaborador de la revista Actualidades, le Jextiendeccidiplomáticorruna tarjeta para el autor de Cantos de vida y esperanza.

Francisco García Calderón

Deuxiéme Secretaire de la Legation du Pérou

presenta sus respetos al Sr. Rubén Darío, su ilustre amigo, y tiene el honor de presentarle al literato peruano, Dr. Jorge Miota y de rogarle que le atienda en sus deseos.

París 12 de enero de 1912

\section{Rue Chateaubriand 4, rue Herschel}

La nota debió haber llegado a manos de Rubén, pues ésta fue hallada entre la documentación que integra el legado dariano que se guarda en la Ciudad Universitaria de Madrid; de lo que no se tiene noticia, es si hubo alguna colaboración del joven escritor en revistas o periódicos, tan asediados en esa época por pertinaces literatos americanos, residentes a como diese lugar, en un París, siempre esquivo $e$ indolente. 
En 1913, tan enigmático como dos años antes, Jorge Miota hace su ingreso en la vida limeña citadina.

V) "Miota...en cuya mirada intensa ya apuntaba el extravío". E. A. C. (Cabotín)

Vuelto a Lima, después de su estada en Montevideo, Jorge Miota empieza una intensa vida literaria en El Comercio y Actualidades, algo menos on Prisma, Siluetas, Cinema, Contemporáneos y Monos y Monadas.

Por esta fecha anima insistente las inquietudes artísticas del joven Beingolea, con el cual le une amistad a toda prueba; a partir de 1902 sus cotidianos paseos vespertinos suelen terminar en el antiguo recinto de la Biblioteca Nacional, el de don Ricardo Palma y González Prada, el de la calle Estudios, en cuyas salas, generalmente vacías, corrigen sus cuentos y artículos que llevarán posteriormente a la redacción del decano nacional. Fue el de estos escritores, un dúo modernisfá que supo hacer literatura "al alimón": Beingolea: "Impresiones veraniegas", Miota: "Notas limeñas", Beingolea: "Croquis bonaerenses" Miota: "Tipos bonaerenses", Beingolea: "Zola y sus libros", Miota: "Zola y su muerte". Por algo afirmaría más tarde "León Gave" en un nostálgico reportaje: "¿Por qué he escrito? -Fue la idea de Miota y de Martínez Luján-".

"Miota era delgado, fino, de tez blanca, nervioso y de ojos grandes, tenía un bigotillo a lo Edgar Allan Poe, buen dibujante a tinta china", así lo recuerdà don Alfredo Munoz, animador de la revista Los Balnearios "Er "Era misterioso distante de lo real", son las reminiscencias de su contemporáneo "Racso". "Nuestra ciudad, tan pródiga en estas amables inteligencias de los graciosos corrillos, no dio nunca tan exquisito causeur" -escribirá "Gastón Roger"- en su "Elogio de la huachafa".

Atisbador del tráfago citadino, fue un vigía pertinaz de Mercaderes, desde donde aguzó su observación para impugnar diferencias suburbanas; mas, algunas veces hundíase en un foso de pesimismo de cuyo fondo le arrancaba sus perpetuas ironías: "contemplando mis aires semi-costeños, —dirá- hácenme parecer un tipo producto híbrido de dos civilizaciones, la del mar y la de la piedra, teniendo en el fondo un corazón de piedra...pómez".

Infortunadamente, los signos de locura se habían manifestado desde su lejana adolescencia, así se colije en una de las crónicas de "Cabotín", escrita en 1903: "Miota dilettante fino y aíslado, en cuya mirada intensa ya apuntaba el extravío".

Jorge Miota sentó plaza en la revista de Castillo, Actualidades, donde se congregaban y escribían Luis Fernán Cisneros, Fausto Gastañeta, Julio Málaga Grenet, Octavio Espinoza "Sganarelle", 
Francisco y Ventura García Calderón, Enrique A. Carrillo "Cabotín", José de la Riva-Agüero, José Gálvez; "Juan del Carpio", Clemente Palma, Leonidas Yerovi y el caricaturista andaluz Sixto Montealegre y Osuna; generación que en su labor pictórica y literaria daba existencia $a$ un bien cuidado y exquisito modernismo.

\section{VI) "El caso del escritor señor Miota". C. P.}

Es el título de una crónica escrita por Clemente Palma en 1913. fecha a partir de la cual la historia de Miota se turba y se alucina, no obstante que la amistad, el periodismo y un amor materno se obstinan por ubicarlo fuera del absurdo. Así con esta intención, La Prensa publica el auto dictado por el juez Ulises Quiroga, sobre el juicio que se seguía por el delito de "secuestración" de Jorge Miota y por el cual se autorizaba "a la madre de éste, doña Serafina González Vda. de Miota, para que lo traslade del manicomio a la Casa de Salud del Dr. Pareja y Llosa". La noticia en primera página fue destacada por el título "El supuesto caso de locura del escritor Miota".

El Dr. David Matto, director del mencionado manicomio, sintiéndose aludido por la publicidad y por el auto evacuado por la Corte, retrucó ipso facto al periodismo, tal vez sin percatarse, que en sus declaraciones y con la exhibición de documentos, develaba la tragedia y la insania del paciente, manifiesta hacía mucho tiempo, en la inquina peligrosa y en la adjetivación procaz hacia la persona y la familia del galeno.

Allí en la dbcumentación está una trilogía de cartas, donde el léxico se enturbia para llegar fealmente a la infraestructura dei dislate (1), alli la carta explicativa del Dr. Augusto Dammert, que testifica una tirria peligrosa (2), allí también el diagnóstico del facultativo argentino Cabred - "se halla atacado de alienación mental revistiendo ésta la forma de delirio sistematizado crónico de persecuciones, enfermedad que hace de Miota un insano peligroso" (3), o la constancia del subprefecto Oreste Ferro, quien sin proponérselo, se envuelve en un hecho patológico (4), o en la misiva aclaratoria de monsieur Des Portes, donde da a conocer cómo la locura y el derecho traicionan los deseos evasivos del paciente (5), hasta llegar a gestión disparatada, para dirimir presuntos agravios y secretas venganzas (6).

Madre e hijo instalados en la Casa de Salud, decidirán, como ella informará: "no volver a ocuparnos de lo pasado para nada y descansar juntos en seguridad completa". Pero, no siempre se cumplen los deseos, pues en 1916, Miota terminante y decidido la convence que deben dejar el Perú para viajar a Buenos Aires. ¿Qué olvidada motivación para la travesía aparece en su cerebro? ¿Acaso la posibilidad de salud en la atención del Dr. Cabred? ¿O 
lejanos recuerdos de pasadas trashumancias? Una anécdota, que en un reportaje trae a colación Manuel Beingolea, hace memorable su figura, a través de una carga de miseria y de ironía:

"Cuando el pobre Miota -el inventor de la palabra huachafa- se iba a Buenos Aires y ya estaba a bordo, un cholito impertinente se empeñaba en venderle una maleta, e insistía una y otra vez, hasta que el literato criollo se enojó y le dijo:

nudo?" iVaya con el hombre! ¿Acaso pretende Ud. que viaje des-

Al poco tiempo de su arribo a la urbe se pierde todo vestigio de su huella, tal vez se afincaría en oscuros conventillos, manzardas miserables o caritativos hospicios. De toda suerte su imagen debió ser patética, viviendo de la caridad o de la buena fe y llevando como lazarillo y custodia a una anciana.

En 1925, llegan a Lima fragmentarias referencias sobre el final del atildado colaborador de Actualidades acaecido en Argentina. La fecha y el lugar exactos hoy en día son triviales, de manera que hilvanar con certeza sus últimos momentos, es arriesgado porque podríamos ingresar a erróneos vericuetos; aunque es muy posible que su vida se haya extinguido "entre negras rejas [...] delante de las cuales Hipócrates y Galeno marmorizados hacen su perpetua guardia" o "entre las paredes de una casa de insania, que regula a extraños autómatas", al menos, así tácito lo registra en El Comercio, el protagonista de esta historia, veinticinco años antes de su muerte, a propósito de un artículo donde incluía una visión del manicomiocestatal capitalino.

\section{"Jorge Puccinelli Converso»}

\section{OBRA}

La obra de Jorge Miota está expresada en prosa, pudiéndose clasificarla en dos géneros específicos: el narrativo y el periodístico. El primero constituido por un conjunto de cuentos y el segundo por artículos y crónicas.

\section{I) Cuentos}

Los cuentos de Jorge Miota conciernen a diferentes asuntos: Históricos: "El amigo de Rabbi", "El beso al maestro"; Sentimentales: "El amor de Armando", "El mesón de Marcelo", "Las dos coronas", "El amor de Ali Mahomed", "El costurero", "Claudina". Con respecto al asunto social, Miota ingresó al cuento indígena, como el mismo lo clasifica en "Huamán el recluta" y la crítica social en "Su señoría... la víctima". En el primero el motivo fundamental es el violento desarraigo del indígena por acción del Esta- 
do -motivo caro a César Vallejo en El tungsteno- el cual suele buscar el elemento social más desvalido para cubrir una obligación, que en teoría a todo ciudadano le concierne. El cuento de trágico final está taraceado de un vocabulario quechua, advirtiéndose que a pesar de la ubicación del autor en el periodo modernista, el relato no deja sabor a pastiche, como algunas perpetraciones, más o menos incaístas de esta índole.

En "Su señoría... la víctima", intenta la crítica de los cargos oficiales de favor, en la peripecia burocrática y sosa de un personaje.

Muchos de sus relatos están situados en lejanos países, lugares exóticos y exquisitos ambientes, tal como "Entre témpanos", "En el País de las hierbas", "El marqués de Derbille", —según lo prescribía el movimiento rubeniano-.

Con referencia a convencionalismos, creencias religiosas y volubles sentimientos femeninos, hizo gala de ironías, escepticismos y sarcasmos en muchos de sus cuentos.

\section{II) Artículos y crónicas}

Jorge Miota dejó una numerosa obra periodística en la que desarrolló Temas modernistas y orientales: "Art Nouveau", "El arte chino en Lima"; Crónicas de viajes: "Impresiones de Montevideo"; Reminiscencias virreinales: "Una reliquia colonial", "Un rincón histórico", y una serie de crónicas acerca de los barrios periféricos limeños.

En la visión dèla la nota capitalinacsiempre está la impronta de un pasado virreingl. Así dirá a propósito de Ancón: "Por más que la civilización haya extendido aqui un puente, por más que el silbido aguro del tren nos recuerde la vida moderna ferroviaria; la imaginación, refleja y aferrada al medio, se adormece con el recuerdo de un pasado latente colonial".

Ensayó también en prosa, comparaciones y metáforas novedosas y grandilocuentes.

La gran rueda de Chicago, dando a la plaza un aspecto de feria y, empotrada al centro de la calle como una gran telaraña vacía en la que hubiese caído los carros como moscas prisioneras ("Barrios Altos: Cinco Esquinas, Cochar$\left.\operatorname{cas}^{\prime \prime}\right)$.

Las joyerías raras sonrisas, mostrando desde el fondo de sus estuches abiertos como bocas el cristalino brillo de sus dientes facetados. ("Notas limeñas").

En otros pasajes la prosa adquiere raros relieves de un viejo sello parnasiano. 
Delante de las puertas en las aceras y en las esquinas, los elegantes,irescos, acabados de afeitar y en traje de fiesta forman barreras con sus cuerpos adosados a las vitrinas cocomo un réclame de los almacenes. ("Notas limeñas").

Y hasta presacia metáforas de un desmesurado vanguardismo.

En las arterias urbonas las largas filas desbordadas de los templos semejan a lo lejos una colosal serpentina arrolladora de iglesias. ("Notas limeñas").

Jorge Miota, prescindiendo de las ciencias arqueológicas y etnológicas $\mathrm{y}$, sólo, a través de la sensibilidad (ante todo no había que olvidar la lección aprendida de Rubén), "En mi jardín se vio una estatua bella, Se juzgó mármol y era carne viva;/ Un alma joven habitaba en ella,/ Sentimental, sensible, sensitiva./, quiso reconstruir el espíritu nativo en el artículo sobre el Cusco: "Una visita".

Todo esto resulta de una grandeza anónima, triste y uniforme en la que el espíritu sepúltase en los siglos de una historia lapidaria que pesa sobre uno como un bloque inmenso [...]. Esta sensación, unida a la mañana invernal, a lo sedentario del medio y a la desorientación histórica, oprime el alma y hace comprender por qué, la única queja de esos pechos fue la "quena" y cómo en leyes agrarias, por ejemplo, el indio fue un ser pasivo, al que se le limitó toda aspiración, reglando su vida por la monotonía del astro preso en las "intihuatanas"

La aspereza del idioma, el aspecto trabajado de la raza, la latente meláncolia, que en todo esfor reside, son pruebas de sensación que tienen para nosotros, los sensitivos, una gran elocuencia de un mutismo secular en el que sólo habla la piedra yacente.

El de Miota fue pues un estilo elaborado, buido, con cierto esmero y relevancia que bien se inscribe en el movimiento modernista.

\section{APENDICE}

El Congreso Antituberculoso

Señores Redactores de La Prensa.

Presente.

Muy señores míos:

Con motivo del próximo congreso antituberculoso que tendrá 
lugar en Berlín y cuyo delegado por el Perú es el doctor Eduardo Aguilar Oliva, según lo anuncian ustedes, me permito dirigirles la presente para su publicación, poniendo a la consideración del público científico el siguiente tema:

¿Cuál es la acción efectiva de la tuberculosis pulmonar y si ésta se contagia por medio de conjugaciones sugestivas, toda vez que por sugestión se llega a percibir hasta el sabor de la boca de otro y el olor característico de tal enfermedad?"

Como se ve, este es un asunto trascendental en materia de salubridad pública y reclama una pronta aclaración por los hombres de ciencia de dicho congreso y de nuestro delegado, pues es urgente que se sepa dicho asunto, tanto para los unos que se delatan si son tuberculosos, como para los que no lo son. Porque de ambos modos podría existir siempre el peligro si lo hubiese!

De ustedes atento y S. S.

Un intrigado.

Octubre 14 de 1913.

Nota. Se suplica se envíe idéntica pregunta a dicha imprenta para establecer la realidad de lo expuesto en ella y que se vea que ello es cierto entre nosotros. Deberá venir firmada o como desee la redacción.

\section{Biblioteca Manicomio.}

Señor doctor Mattoorge Puccinelli Converso» Presente.

\section{Señor Doctor:}

No obstante haberle dado la mano sin asesinarlo como Ud. ha inventado, así como mi madre manifestarle también no tenerle la menor animadversión, sigue usted en la tarea de sugestionarme con toda clase de torturas; entre ellas los hálitos y conjugaciones de tuberculosos, para enfermarme, sin que ello pertenezca a un sistema que podría parecer de oscilaciones de analogías, si usted fuese un sabio que quisiera establecer este sofisma para defenderse. Pero como esto es infame solamente le dirijo la presente para que la enseñe usted a quien quiera y así se conozca lo que usted hace mientras que la corte que ya sabe todo esto lo meta...gusanos, moscas, etc. como lo hizo usted se refiere y tortura llamando "medicina de las pasiones" y que no es otra que la pobre viuda de Samanés donde empezó usted su vida de sugestiones desde la época de Cáceres!... 
Esto no es locura, pues usted la conoce y fue usted alguna vez a visitarla no sé si después de haber venido de Alemania donde hizo usted su repaso de sus estudios como decía Emilio Campo aquel que se suicidó con una escopeta en casa de Leoncio Samanés, civilista.

Agregaré que su habilidad en sugestión llega hasta la entomología: hormigones, arañas, gusanos, moscas, etc, como lo hizo usted con los camellos y el león del Parque Zoológico y de lo que le hablé habiendo usted aprobado con la cabeza estando "vestido de negro" por más señas.

Jorge Miota.

Nota. Le pongo entre comillas lo de vestido de negro, porque también en casa del doctor Odriozola cuando éste salió a verme usted dijo por telepatía: "Esto se ha hecho para vestirse de negro"; y así quiero recordarle el abuso a usted que hace de ello su clave o clef! (en francés: por supuesto).

Usted que conoce el sistema "celular" perdone este papel, casi de presidiario merced a su exinfluencia.

Recurso que Miota procuraba hacer firmar a los empleados

Excmo señor Presidente de la Iltma. Corte Superior.

\section{Excmo. señor:}

\section{"Jorge Puccinelli Converso»}

Los suscritos empleados del Manicomio, ante V. E. exponen: que víctimas de la sugestión del doctor David Matto, nos hallamos fatigados y molestos en nuestros servicios que, desde luego, nada tienen que ver con la sugestión médica de dicho Director en el establecimiento donde trabajamos, pues jamás nos ha advertido ser éste un sistema que debemos acatar como empleados.

Por tanto:

A V. E. rogamos cese este fenómeno molesto en nuestras labores y que redobla el trabajo creando peligros como podrá exponerlo el doctor Wenceslao Mayorga, que es el que viene en persona mientras que el doctor Matto asiste en sugestiones!

Lima, Manicomio, diciembre 27 de 1913. (1). 
Lima, noviembre 6 de 1913.

Señor doctor don David Matto.

Presente.

A pedido de usted me es grato escribirle la presente que es la expresión fiel de lo que de viva voz le dije a usted ayer.

Considerando conveniente que cuanto antes se haga toda la luz posible en el asunto que se refiere al Señor Jorge Miota, creo un deber de mi parte el contribuir para ello con los siguientes datos recogidos en mi consultorio en los primeros días de agosto próximo pasado.

El señor Miota vino en esa fecha, según me dijo, con el objeto de comunicarme que alguien lo había sugestionado para hacer un daño a otra persona y que se sentía impulsado a ello.

En el curso de la conversación procuré que me indicara el nombre de las personas a quien él se refería, no lográndolo desgraciadamente. Sobre el particular se limitó a decirme que su palabra de honor estaba empeñada y que sólo quería dejar constancia ante mí, que él no sería responsable de cualquier acto que hiciera contra esa persona, etc.

Dado el estado de excitación nerviosa en que se encontraba el señor Miota en esos momentos, procuré tranquilizarlo, ofreciéndole también acompañarlo donde un especialista de enfermedades nerviosas, cosa que no aceptó.

Es todo lo que tiene que decir a usted su atento y S. S.

\section{"Jorge Puccinelli Converson Augusto Dammert (2).}

El médico que suscribe certifica:

Que Jorge Miota, peruano, de 35 años de edad, soltero, internado en el Manicomio de Lima, se halla atacado de alienación mental revistiendo ésta la forma de delirio sistematizado crónico, persecuciones, enfermedad que hace de Miota un insano peligroso y que exige su hospitalización por un tiempo prolongado.

A pedido de los doctores Wenceslao Mayorga y Estanislao Pardo Figueroa, y después de un prolijo examen de Miota, otorgo el presente, en Lima, el 17 de noviembre de 1913.

D. Cabred (3).

Lima, 15 de noviembre de 1913.

Hago constar por la presente que en mi carácter de prefecto del departamento y a solicitud del señor doctor David Matto, hice 
llamar a la señora Serafina González viuda de Miota, quien convino conmigo:

1.-Que su hijo se encontraba realmente atacado de locura, como no podía dejar de reconocerlo.

2.-Que convenía asimismo en que fuera conducido al Manicomio, y puso como condición que fuera bien tratado y que no lo asistiera el doctor Matto, lo que puse en conocimiento de dicho doctor, quien aceptó gustoso el no ocuparse absolutamente del enfermo Miota, el que estaría bajo la dirección del médico del departamento de hombres, señor doctor Mayorga.

No se explica cómo después de lo referido la señora de Miota haya interpuesto demanda judicial por secuestración arbitraria de su hijo.

O. Ferro (4).

Legation de France.

\section{Lima, de 2 janvier 1914.}

Monsieur le docteur:

J'ai 1 honneur de répondre á votre lettre du 23 décember dernier.

C'est au mois de Juin de l'année derniére que Mr. Miota s'est présenté á la chancellerie de cette Légation pour demander à étre naturalisé français. Ma chancellerie lui fit observer qu'il n'avait pas le temps voulu dé résidence en France pour obtenir cette naturalisation et que d'ailleurs une condition indispensable était de résider en France au móment lae la demande."

Mr. Miota insista pour que sa requéte fut transmise au Ministére des Affaires Etrangéres de la Republique, accompagnée des documents qu'il présentait á son appui. Rien, en ce moment, ne dénotait que ses facultés mentales fussent altrées, car il s'emprima avec calme et lucidité.

Il revint quelque temps après et ce fut alors qu'il manifesta au chancelier de cette Légation qu'il avait été suggestionné à Paris où, au moment de voir défiler un régiment, sur les Boulevards, il avait reçu sur la nuque un coup de poing donné par une main invisible, personne ne se trouvant derrière lui, quoiqu'il se fut retourné vivement.

Ce fut alors que non Chancellier comprit que Mr. Miota souffrait d'une obsession mentale. Il revint, une trosième fois, pour demander si cette Légation avait reçu une rèponse de Paris au sujet de sa demande. Dans son désir de prover son affection pour la France et les titres qu'il invoquait a l'appui de sa requéte il fit valoir alors que le soufrement français lui devait bien une compen- 
sation puisque c'est en France qu'il avait été suggestionné, ce qui, d'ailleurs, venait de se répéter ici, car, en passant sous les balcons du Cercle français, il s'était tirer d'en haut par les cheveux. Tout cela dit avec le méme calme et sans la moindre apparence d'exaltation.

Ma chancellerie n'a plus revu M. Miota et d'ailleurs sa demande de naturalisation a été rejétée.

Agréez, monsieur le docteurs, les assurances de ma considération distinguée.

Des Portes (5).

Monsieur le docteur David Matto.- Plaza Bolognesi No. 467.Lima.

\section{Lima 2 junio 1914}

\section{Señor Doctor:}

Tengo el honor de responder su carta del 23 de diciembre último. El mes de enero del año pasado el señor Miota se presentó a la Cancillería de esta Legación para solicitar ser naturalizado francés. Mi cancillería le hizo observar que él no tenía el tiempo requerido de residencia en Francia para obtener esta naturalización y que por otra parte era condición indispensable residir en Francia en el momento de la solicitud. El señor Miota insistió en que su solicitud fuese transmitida aI Ministerio de Asuntos Extranjeros de la República, acompañada de los documentos que presentaba en apoyo de ella, en ese momento, nada demostraba que sus facultades mentales estuviesen alteradas, pues se expresaba con calma y lucidez.

Volvió algún tiempo después y entonces manifestó al Canciller de esta Legación que en París había sido objeto de un acto de encantamiento en el momento en que veía desfilar un regimiento en los bulevares, entonces recibió en la nuca un puñetazo dado por una mano invisible, no vio a nadie detrás de él a pesar de que se hubiera vuelto rápidamente.

Entonces mi Canciller comprendió que el señor Miota padecía una obsesión mental. El volvió por tercera vez, para preguntar si esta Legación había recibido respuesta de París respecto de su solicitud. En su deseo de probar su afecto por Francia y los títulos que invocaba en apoyo de su requerimiento argumentó entonces que el gobierno francés le debía una compensación porque en Francia había sido víctima de un encantamiento lo que por otra parte se había repetido aquí pues al pasar bajo los balcones del Círculo Francés, había sentido que desde arriba le tiraban de los 
cabellos. Todo esto dicho con la misma calma y sin la menor apariencia de exaltación.

Mi Cancillería no ha vuelto a ver al señor Miota; por lo demás, su solicitud de naturalización ha sido rechazada.

Reciba usted señor doctor las seguridades de mi distinguida consideración.

Des Portes

Señor Doctor David Matto. Plaza Bolognesi No. 467.- Lima.

(Traducción del profesor Edgardo Albizu P.)

Señor doctor David Matto.

Ciudad, 10 de enero de 1914.

Presente.

Muy señor mío y amigo:

Dando a usted contestación escritar a la pregunta que se dignó hacerme, con referencia a lo que medió entre mi persona y el se ñor Miota, paso a absolver gustoso su deseo.

Hacía largo tiempo que de vista tan solo conocía al señor Miota, entre ambos no existía vínculo alguno de amistad; por lo tanto me sorprendió mucho el que se llegara a mi casa y solicitara verme, alegando que era asunto de gran importancia lo que a ello le obligaba.

Una vez en su presencia, me manifestó después de larga peroración, que entre él yi usted existía iunocdio irreconciliable y que tan sólo podía terminar batiéndose, pues su vida estaba en serio peligro, si usted no desaparecía antes de que fuera él el sacrificado, concluyendo por exigirme fuera yo uno de sus padrinos, retando a usted al terreno del honor.

Me defendí de tan absurda pretensión, tanto por las consideraciones personales que usted me merece, cuanto porque no me ligaba al señor Miota vínculo alguno de amistad para apadrinarlo, pero como su insistencia era mayor a cada instante le hice presente que se buscara él otro padrino, $y$ que entonces puede que yo me decidiera a aceptar; pero insistiendo en que era yo el que debía buscarle, ya fastidiado por su impertinencia hícele comprender que era él el que debía buscar a otras personas amigas para que lo apadrinaran; no se desanimó por mi negativa y continuó buscándome, sin que yo le recibiera; no volví a verle.

Siendo esto cuanto medió en tan molestoso asunto, dejo cumplidos sus deseos y me repito de usted atento y S. S. 
1. CUENTOS

\section{EDICIONES}

a) Recogidos después en antologías generales

La pared de enfrente. Act. Rev. Año I. No. 26. 14 julio 1903.

El pasado (El pasado muerto). ComE. 19 julio 1903, p. 4.

Hacia el pasado. Con. Rev. Año I. No. 5. 1 o junio 1909, pp. 230-233.

Alma Nueva. Act. Rev. Año II. No. 50. 14 enero 1904.

b) No recogidos en libros

Lo prometido. LI. Año II. No. 36. 15 julio 1900.

Entre témpanos (Velados moscovitas). Act. Rev. Año I. 3 enero 1902.

La Ecuyere. ComE. 29 junio 1902, p. 4.

El aprendiz de fragua. ComE. 17 julio 1902, p. 3.

El marqués de Derbille. ComE. 17 agosto 1902, p. 4.

La catástrofe. ComE. 24 agosto 1902, pp. 3-4.

Adgine. ComE. 7 seticmbre 1902, p. 4.

Psicología suicida. ComE. 23 setiembre 1902.

Doña Joaquina. ComE. 24 setiembre 1902, p. 3.

Emma. ComE. 14 octubre 1902, p. 4.

Las dos coronas. ComE. 6 noviembre 1902, p. 4.

Entre llamas. ComE. 9 noviembre 1902, p. 4.

El mesón de Marcelo. ComE. 20 noviembre 1902, p. 3.

El té de la Baronesa. ComE. 14 diciembre 1902, p. 4.

Noche de Navidad. ComE. 25 diciembre 1902, pp. 2-3.

El amor de Alí Mahomed. ComE. 4 enero 1903, p. 4.

El amigo de Rabbi.lComE. a1 cenero 1903, p. 4.

Huamán el recluta (Cuento indígena) ComE. 1 febrero 1903, pp. 3-4.

El amor de Armando. Act. Rev. Ano I. No. 6. 14 febrero 1903.

Huamán el recluta (II). ComE. 15 febrero 1903, p. 4.

La muerte de Pierrot. ComE. 24 febrero 1903, pp. 3-4.

¡El Porvenir!. . . ComE. 3 marzo 1903, p. 4.

Historia de un retrato. ComE. 15 marzo 1903, p. 4.

Lady Heliet. ComE. 8 abril 1903, p. 4.

El beso al Maestro. Act. Rev. Año I. No. 14. 14 abril 1903.

Por un sou. Act. Rev. Año I. No. 16. 28 abril 1903.

La pared de enfrente (De Pierre Loti). Año I. No. 26. 14 julio 1903.

Su señoría...la víctima. ComE. 7 junio 1903, p. 3.

Su señoría. . la víctima. ComE. 19 junio 1903, p. 4.

Su señoría...la víctima. ComE. 21 junio 1903, pp. 3-4.

Su señoría...la víctima. ComE. 5 julio 1903, p. 4.

Su señoría...la víctima. ComE. 12 julio 1903, pp. 3-4.

El triunfo de un imposible. ComE. 13 agosto 1903, p. 3.

El pasado. ComE. 19 julio 1903, p. 4.

El sueño del vagabundo. ComE. 16 agosto 1903, p. 4. (A José Santos Chocano). 
La Chauffeuse (Diálogo de Henri Lavedan). ComE. 30 agosto 1903, p. 4.

La rosa encarnada. ComE. 27 setiembre 1903, p. 5.

El sueño de Adán. ComE. 8 noviembre 1903, p. 4.

Alma vieja. ComE. 1 enero 1904, p. 4.

El corrector de pruebas. Act. Rev. Año II. No. 49. 7 enero 1904.

Alma nueva. Act. Rev. Año II. No. 50. 14 enero 1904.

El pasado muerto. Act. Rev. Año II. No. 55. 22 febrero 1904.

En el país de las hierbas. Act. Rev. Año II. No. 63. 24 mayo 1904. (A Angel Vega Enriquez).

El regreso. Act. Rev. Año III. No. 72. 14 julio 1904. (A José Fiansón).

La taza de té. Act. Rev. Año III. No. 100. 25 febrero 1905.

EI costurero. Act. Rev. Año III. No. 116. 17 junio 1905.

Claudina. Act. Rev. Año V. No. 234. 21 setiembre 1907.

El choque. Act. Rev. Año V. No. 237. 12 octubre 1907.

\section{ARTICULOS}

Los Conquistadores. Pe. IluE. 11 febrero 1888, p. 8.

Tipos bonaerenses (D'Aprés nature). Primera Serie. "El Cajetilla". ComE. 20 mayo 1900, p. 4.

El invierno. Balada del norte. ComE. 3 junio 1900. p. 4.

Las dos riberas. ComE. 9 febrero 1902. (A Manuel Beingolea).

Los chinos en Lima. La Colonia. El callejón de Otayza. La suerte china. Casas de juego. Teatro "Odeón". Almacenes de objetos artísticos. Asiáticos. Médicos herbolarios. Templos. ComE. 9 marzo 1902, p. 4 .

Barrios de Lima. (Abajo el Puente). ComE. 6 abril 1902, p. 4.

Notas limeñas. ComE. 27 abrif 1902, p. 4.

Barrios Altos II. Barbones. ComE. 13 mayo 1902, p. 4.

Barrios Altos. El Cercado. ComE. 28 mayo 1902, p. 4.

Impresiones de Montevideo. ComE. 8 junio 1902, p. 3.

Impresiones de Montevideo (II). ComE. 22 junio 1902, p. 4.

Una visita a Ignacio Merino. El Museo de la Exposición. ComE. 14 julio 1902, pp. 3-4.

Barrios Altos VI. Cinco Esquinas. Cocharcas. ComE. 20 julio 1902, p. 4.

Barrios del camal. ComE. 10 agosto 1902, p. 4.

Zola y su muerte. ComE. 7 octubre 1902, p. 3.

Barrios de Lima. Monserrate VII. ComE. 16 noviembre 1902, p. 4. Nuestros domingos. Act. Rev. Año I. No. 12. 28 marzo 1903.

* Tipos y costumbres (I). "Las' huachafas". ComE. 19 abril 1903, pp. 3-4.

* Aunque estos artículos no llevan firma, el estilo de ellos guarda gran similitud con aquellos que fueron firmados por Jorge Miota. 
* Tipos y costumbres (II). Los fás "De medio pelo". ComE. 3 mayo 1903, p. 4.

Hacia Anécón. (Notas de verano). Act. Rev. Año III. No. 17. 10 mayo 1903.

Inri. Act. Rev. Año II. No. 59. 7 abril 1904.

El pro de la lectura. ComE. 31 mayo 1904, p. 3.

Ellas... (Tríptico). Act. Rev. Año II. No. 74. 28 julio 1904.

El hijo de Jairo. Act. Rev. Año II. No. 84. 14 octubre 1904.

La bohemia y el vulgo. Act. Rev. Año II. No. 85. 21 octubre 1904.

El arte chino en Lima. De tiendas. Act. Rev. Año II. No. 88.14 noviembre 1904.

La locomotora y el automóvil. Act. Rev. Año II. No. 90. 28 noviembre 1904.

Nuestros institutos médicos. El masaje y la gimnasia médica. Act. Rev. Año II. No. 92. 30 diciembre 1904.

La calle. Act. Rev. Año III. No. 94.14 enero 1905. (Para el lápiz de Sixto).

Art Nouveau. Act. Rev. Año III. No. 95. 21 enero 1905.

Aurora espiritual. Luc. El. Año VIII. No. 95. 20 abril 1905.

Impresiones de Montevideo. Luc. El. Año IX. No. 113.12 setiembre 1905.

Días funestos. Mon. y Mon. Rev. 24 febrero 1906.

Lima religiosa. Act. Rev. Año IV. No. 159. 14 abril 1906.

Lima pintoresca. Act. Rev. Año IV. No. 752. 1906.

Canto a la noche. Act. Rev. Año V. No. 206. 9 marzo 1907.

Una visita al "Sacsahuamán". Impresiones de viaje. Pris. Rev. Año III. No. 34,16 marzo 1907. (A Clemente Palma).

Hacia el Plata. Mon. $\mathrm{y}$ Mon. Rev, 16 marzo 1907.

Nuestras sierras. Act. Rev. Año V. No. 211. 13 abril 1907.

Crónicas limeñas. Act. Rev. No. 264. 26 mayo 1908.

El Señor de los Milagros. Cin. 24 octubre 1908.

Una reliquia colonial. Sil. Rev. Año 1. No. 2. 4 noviembre 1908.

Un rincón histórico. Sil. Rev. Año 1. No. 4 . 18 noviembre 1908.

"El Choqquequirau". ComE. 18 abril 1909, pp. 5-6.

La buena ventura. G. B. Año I. No. 29. 22 agosto 1909, p. 11.

\section{REFERENCIAS}

Maurilio Arriola Grande. Diccionario literario del Perú. Huancayo, Universidad del Centro, 1968, pp. 334-335.

Ezequiel Balarezo Pinillos (Gastón Roger). Antología peruana. Lima, 1944.

Enrique A. Carrillo (Cabotín). Viendo pasar las cosas. 2a. ed. Lima, Editorial Antonio Lulli, 1957.

Mario Castro Arenas. La novela peruana y la evolución social. 2a. ed. corr. y aum. Lima, José Godard Editor, 1968, p. 126. 
"El caso del escritor señor Miota". En La Cŕónica. Lima, enero 13 1914 , p. 4.

"El asunto Miota. Una carta". En La Prensa. Itimá; enero 18 de de 1914 , p. 6.

"El caso Miota. Lo que justificó su reclusión en el manicomio. Hablando con el Dr. Matto. Necesidad de una legislación preventiva". En La Prensa. Lima, enero 18 de 1914, p. 4.

El Primo Basilio (Seud. de Manuel A. Bedoya): "Impertinencias". En Monos y Monadas. Lima. Año I. No. 40. Setiembre 29 de 1906 , pp. 2-4.

Alberto Escobar. La narración en el Perú. Estudio preliminar, antología y notas. 2a. ed. Lima, Librería-Editorial Juan Mejía Baca, 1960, pp. 162-164.

Martha Hildebrandt. Peruanismos. Lima, Moncloa-Campodónico Editores, 1969, pp. 205-208.

Juan Apapucio Corrales (Seud. de Clemente Palma). Crónicas político-doméstico-taurinas. Con un glosario del argot limeño. Prólogo de Clemente Palma y epílogo de José Gálvez. Lima, Compañía de Impresiones y Publicidad, 1938, p. 270.

Enrique Labrador Ruiz: "Encuentro con José Gálvez". En La Nueva Democracia. Nueva York Vol. XXXVI. No. 4. Octubre de 1956, pp. [44]-47.

"La reclusión del señor Miota. El supuesto caso de locura del Sr. Miota. La justicia ordena su traslado a la clínica del Dr. Pareja y Llona". En La Prensa. Lima, enero 12 de 1914, p. [1].

César Francisco Macera: "Manuel Beingolea en la intimidad". En Fanal. Lima. Año V.No. 23. 1950, Tpp. 22-25.

Monsieur Treville (Seud. de Rómulo Paredes): "Revista de monos... y monadas". "En Monos G Monadas. Zima. "Año I. No. 40. Setiembre 29 de 1906, p. 4.

Willy Pinto Gamboa. Epistolario de Rubén Dario con escritores peruanos. Lima-Santiago de Chile, Universidad Nacional Mayor de San Marcos-Universidad de Chile, 1967, p. 31.

Conversaciones con don Alfredo Muñoz, director de la revista 'Los Balnearios'; febrero 18 de 1966. Inédito.

- Conversaciones con don Oscar Miró Quesada (Racso); abril 14 de 1976. Inédito.

Quinito (Seud. de Leonidas Yerovi): "Semana cómica". En Monos y Monadas. Lima. Año I. No. 2. Enero 6 de 1906, pp. 2-3.

Emilia Romero de Valle. Diccionario manual de literatura y materias afines. Lima, Universidad Nacional Mayor de San Marcos, 1966 p. 208.

Luis Alberto Sánchez. La literatura peruana; derrotero para una historia cultural del Perú. Lima, Ediciones de Ediventas, 19651966 , t. IV, p. 1221. 
Rubén Sueldo Guevara: "Notas sobre dos cuentistas cuzqueños". En Cultura Peruana. Lima. Año XV. Vol. XV. No. 83. Mayo de 1955 , pp. [14-15 y 56].

- Narradores cuzqueños. Selección y notas de ... Cuzco, Editorial H. G. Rozas, 1958, pp. 27-36.

\section{ICONOGRAFIA}

Foto y firma de Jorge Miota. En Actualidades. Lima. Año II. No. 73. Julio 21 de 1904.

Caricatura de Jorge Miota por A. Valdelomar. En Gil Blas. Lima. [Año I. No. 28. Agosto de 1909], p. 12.

\section{ABREVIATURAS DE LAS REVISTAS Y PERIODICOS CITADOS EN LA BIBLIOGRAFIA}

Act. Rev.

Cin.

ComE.

Con. Rev.

CroL.

G B.

Luc. El

LI.

Mon. y Mon. Rev.

N. Dem. Rev.

Pe. IluE.

Pris. Rev.

Sil. Rev.
Revista Actualidades.

Cinema.

El Comercio. Lima.

Contemporáneos.

La Crónica. Lima.

Gil Blas.

- El Lucero.

- Lima Ilustrada. Revista Monos y Monadas.

Revista La Nueva Democracia.

El Perú Ilustrado.

Revista Prisma.

Revista Siluetas.

"Jorge Puccinelli Converso»

\section{SELECCION DE CUENTOS Y ARTICULOS}

\section{ALMA NUEVA}

Es preciso creer -dijo Mauricio- que al menos una vez por año viene a visitarnos con la primavera un alma nueva. No de otro modo podrían explicarse esas extrañas eflorescencias de que es objeto nuestro espíritu, esos anhelos que invaden nuestro ser i que en el canto de las aves, en el brotar de las flores, en la luz, en el ambiente todo, parece aportarnos esta estación. ¿No habéis sentido qué ligera, qué nueva i buena parece la vida al despertar? Alzanse entonces en nuestro espíritu raras nociones de la existencia, una alegría juvenil nos invade i parece que las primeras épocas de nuestra vida retornasen a nuestro ser, en el claro sol que penetra por la ventana, en el ambiente luminoso que nos envuelve, en el cielo azul: esos primeros días de nuestra adoles- 
cencia, cuando, felices i con el alma sana, sentíamos germinar los indefinibles anhelos de la pubertad; alegrías pueriles rayanas en delirio, indecisas nostalgias de goces presentidos i no explicados, libertades de ave i batir de alas!...

¡I qué lejano nos parece todo, cómo se desvanece al despertar ese peso de la vida, i qué liviano se agita el pecho! Diríase que el hombre, malo i torpe de ordinario, reconquista el bíblico Paraíso i toma nueva posesión de éli recomienza su vida, reconstruye sus amores, aviva sus energías y dirige sus actividades en pro de una felicidad que ya no se desvanecerá. Late el pecho con emoción, la mirada es clara, ágiles los movimientos i un vehemente anhelo de expansiones adoríferas i campestres, un deseo continuo de actividad, de cambio de localización, de viajes, hace dilatarse nuestros sentidos i lanzarnos de la cama, con la alegría retozona i traviesa de un colegial en asueto. La infancia, la libertad sin aulas, es lo que parece agitarse en nosotros i hacernos olvidar, como al colegial en vacaciones, el recomienzo de nuestras bregas.

- En estos raros anhelos, en esa desmedida alegría que me invade -insistió Mauricio-he creído ver siempre un alma nueva. ¿Es qup a través de la gastada envoltura de nuestros cuerpos, guardamos, como guarda la tierra, nuevos gérmenes que nos hacen retoñar, o es sólo la parte animal la que late en nosotros en esta época del celo? Ambas; ambas cosas son las que se verifican en nosotros; i a través de las manifestaciones sicológicas, es el alma que nos impele a estas nuevas formas de vida reconquistada. ¿Qué hermosalnos parece entonces la metáfora del Paraíso, que la Primavera renueva!

En todos estos gritos del ser humano, en la "crepitación del sol en las eflorescencias de la tierra, en la savia potente i vivificadora que nos envuelve, parece residir el alma del Paraíso perdido, que un alma nueva reconquista.

La fantasía arrastraba a Mauricio. Creí oportuno objetarle:

- Pero...todo eso es altamente subjetivo. ¿Quién podría asegurar que lo que me dices les pasa a todos, a mí por ejemplo, i que no es eso sino un estado particular de ánimo, mayor o menor dosis de bilis o cierta predisposición optimista y paradójica de tu parte?

- ¿Quién?...¿Has leído acaso a Baudelaire? ¿Conoces sus Paraisos artificiales?...

- ¡Baudelaire ¡bah!...Un parnasiano, un soñador que vivió alimentando sus fantasías con opio, і стеyéndose transportado al quinto cielo en cada borrachera con éter i... Sólo conozco sus Flores del mal, i eso, desde que tengo a Fifi... una Mandrágora!

Pues bien, esos "Paraísos artificiales" de que nos habla, son el Paraíso humano, que el hombre, harto gastado, trata de recon- 
quistar, por medios artificiales, por la morfina, el opio, etc., sentidos todos con los que Baudelaire narcotizado, nos hace entrever las dichas de ese Paraíso con el que el hombre sueña. Esa es su mente. Harto miserables, buscamos por medios artificiales lo que a nuestras naturalezas falta, pervertirnos ésta, i desviándola, como tú lo haces con tu Mandrágora, desviamos el objeto de nuestra vida. Ya que no sabemos vivir, busquemos el arte de la vida; preparemos nuestras naturalezas como se prepara la tierra para las siembras i dejemos que la Primavera, paraíso, reconquistado, nos devuelva los gérmenes de una vida nueva, de un Alma nueva, que tanto necesitamos i que ella nos aporta... Querido: en la naturaleza hay fósiles, tú eres uno de ellos, i la Primavera más potente no bastaría a devolverles a la vida primitiva... Yo, siento que ella me aporta esa "alma nueva".

Calló Mauricio. Había tal convicción en sus palabras, que no quise objetarle. Era un espiritualista, i entre Platón y Darwin, a quien yo profeso gran culto por habernos revelado el Origen de nuestra Escecie, no cabía la controversia.

Se había arrellanado en el sillón i me miraba con aire de triunfo, persuadido de lo incontrastable de sus argumentos, por mi silencio.

En ese momento entró Fifi y me habló al oído: quería una pastora nueva con guindos de primavera, que había visto en el Bonmarché. Consulté mis bolsillos; como me faltase un duro, opté por decir a Mauricio:

- Me has convencido; tan creo en "Alma nueva" que ahora mismo. voy a comprarle a fífi una. T. Préstame un duro. añadió:

Introdujo Mauricio la mano en el bolsillo i sacando el duro,

-Tómalo.

I lo hizo saltar alegremente en el aire.

(En Actualidades. Lima. Año II. No. 50. Enero 14 de 1904).

\section{LADY HELIET}

Hacen seis meses que las pupilas azules de la señora Crofort han penetrado en el alma de Guillermo, introduciendo en su espíritu, junto con esos parches de cielo albionés, un incesante y continuo malestar, que le impide todo trabajo. Decididamente está enamorado. Impenetrable y fría, autócrata, inaccesible, Lady Haliet ha llegado a despertar en el cajero una vehemente pasión; a formular en su espíritu con su crueldad azul, un ensueño. Porque todo ella es azul. Tiene en su epidermis todas las gamas del color de sus ojos, del lapislázuli difumado, esfumado, circulante...Diríase que por sus venas corre cobalto líquidol... 
Lady Haliet lee. Con los pies en el calorífero, espera la llegada de míster Crafort. Cuando éste penetre, caerá el Puck sobre la mesa y, de pie después de estrechar la mano de su esposo, Lady Haliet correrá las persianas, difumada por la luz de la pantalla y más azul. Después para el corazón oprimido del cajero, en la noche entenebrecida, tan sólo una franja de luz, trasparen-" tada por una rendija!...

Guillermo sufre. Este ensueño se ha apoderado de su espíritu de tal modo, está tan tenazmente grabado en su cerebro, que la visión le persigue en todas partes....Si al menos pudiese verla!... Pero le es imposible, sólo contempla la británica figura de míster Crafort, con su aspecto depilado y duro de Pastor, que le da a la vez que un sello de unción sacerdotal, cierto ascetismo de tribuno a lo Pitt, que contrasta notablemente con la rigidez nudosa y membruda de sus músculos, con sus anchas espaldas y con la arista vigorosa de su maxilar inferior. Inflexible y cronométrico, Mr. Crafort parece ligado a todos los relojes de la oficina, desde el disco pleno de punteros gordos, de su escritorio, hasta el lejano y descomunal de la Pampa, cinco kilómetros distante... Su rodar es compasado como el tíctac de un cronógrafo, y parece estar dotado de perpetua cuerda. .Lady Heliet?...

El matrimonio podría traducirse en una compañía insular, despótica y autocráticamente implantada en plena Pampa, que la absorvencia de los esposos Crafort ha convertido en un laboratorio de nitrato, desde hace seis meses.

Primero llega el uno; se instala, arbola la bandera de compañía y se hace rey. Después to otra rubiay azul, con su gran paletó "sastre", serena y fría, con un Shakespeare en su maleta y un álbum de esquechs en una mano; en la Otra, la caja de tafilete negro de una "kodaks" y un inicotillo...

Medio año que Lady Haliet, ligada a míster Crafort como pudiera estarlo a un sillón de paja china, a los bibelots de su consola y al manto de damasco de su five o clocks; imperturable sigue anacrónica como una deidad a la cual hubiera sujeto el mágico anillo de un Nibelungen!... Guillermo la contempla. Desde las alturas de su silla zancona, en el pupitre do la Caja, con los codos sobre el "Debe" y el lapicero en una oreja, sueña con ese amor jerárquico que la posesión de un sindicatman ha hecho imposible... El se envejece. Doce años de destierro en la soledad de la pampa salitrosa, había llegado a infiltrar en su espíritu el deseo vehemente de las expansiones urbanas, a hacerlo soñar como una corta licencia y con el regreso a su país; pero he aquí que ahora un cambio imprevisto de razón social, o acaso la poderosa influencia de los trust del norte, han vuelto a encadenar su vida a esas odiosas estepas de nitro, y a hacer que se le deniegue la licencia... No es ya el automatismo rudo de una labor continua, la tor- 
tura incesante de los guarismos la que lo encadena, es otra; otra nueva y desconocida para él hasta entonces: el amor! ... ¡Y qué amorl...Un imposible de cabellos rubios, Lady Haliet, la mujer del jefel...

$Y$ en su espíritu disciplinado por doce años de trabajo, en su conciencia regulada por el deber inflexible del empleado, algo cruel y poderoso, ciego e impulsivo estalla derrepente y le hace levantarse de su silla. Está tentado de gritarla su amor, de declarárselo, salvando la pequeña distancia que media entre el escritorio y su departamento...

Pero el toque insólito de una campanada le hace volver el rostro. ¿Cómol es la una de la mañana y míster Crafort no vuelve?... Cierra lentamente el pesado libro del "Debe" y trepando sobre su zancuda resuelve esperarlo. Lady Haliet no se acostará hasta que éste no llegue. Y va a tornar a sus sueños, cuando el sonido de una detonación lejana le hace ponerse de pie y sondear las tinieblas. Con la vista enfocada por ambas manos y la nariz achaparrada contra los cristales, atisba por la ventana, hacia el campamento: en la vasta negrura de la pampa, sólo alcanza a distinguir la zona iluminada por su ventana; más allá, hacia el mar, se cierne el cielo tachonado de astros sobre el Pacífico. Con la mirada hundida en las tinieblas, Guillermo piensa en míster Crafort. Un disturbio entre el "corrector" y el capataz, lo ha obligado a partir apresuradamente... Crúzale una idea al pronto y piensa en Lady Haliet ¿Habrá oído la detonación?... Posible que no. $Y$ en sus ojos présbitos, a través de sus lentes de oro, retrátase una determinación.

La hora avanza $y$ un viento helado proveniente del sur, sacude los cristales. Guillermo siente un presagio agorero, y al dirigir nuevamente su vista sobre el reloj que ritma la soledad de la noche con su tictac, piensa en la "Historia de un corazón revelador" de Poe, al que ha leído en sus ocios. Luego en Eleonora, en esa Beatriz del poeta de Boston; y encontrando un símil compara a ésta con la inglesa... Muy joven aun estuvo en Chicago; allí aprendió teneduría, y el idioma... Recuerda perfectamente aquellas bellezas chicagonenses que le volvieron el seso... pero ninguna como la inglesa, como Lady Haliet, esa esfinge británica mitad mujer, con pupilas de turquíl...

$Y$ en una evocación fogosa de su juventud, en una fuerza regresiva de sus primeros años, corre hacia la puerta; abre las batientes del mamparón, y se dirige resueltamente al departamento de Lady Haliet. Sí, hablará con ella; la preguntará por míster Crafort $y$, fingiendo una hipócrita solicitud, le manifestará sus temores por el jefe... le insinuará lo del disparo.

$Y$ en su estado de ánimo, febril e iluso, acaricia la idea de una aproximación creada por las circunstancias, que salve la distan- 
cia con la comunidad de un afecto; y la idea de que hubieran podido asesinar a míster Crafort, le hace pensar en sus logros...

Lady Haliet abre. Fría y severa, con su hieratismo británico, ahoga súbitamente en el alma del cajero todos sus sueños, y sus pupilas fijas y verdes en ese momento, marcante para siempre la distancia que media entre el sentimiento sajón y la efusión latina. Confuso, Guillermo trata de formular una disculpa; pero un "good morning", seco y cortante, le hace volver el rostro... Es míster Crafort que llega.

(En El Comercio. Lima, abril 9 de 1903, p. 3).

\section{POR UN SOU}

Sentado ante una de las mesas de un boulevard exterior entreteníame una tarde gris viendo el desfile ante mi copa de absinthe. Había caído el otoño i las primeras ráfagas heladas, azotando el rostro, deshojaban los árboles. Un lampo triste doraba las cornizas altas de los edificios i, melancólicamente, se marchaba el sol. Salidos del barrio Latino grupos hostiles de estudiantes melenudos, cruzaban la ciudad gritando: "Campuez Zola!".

El proceso Dreyfus convulsionaba París íntegro, i el nombre de Emilio Zola bajo su "Je acusse" i ligado al anatema, había sido una fulminación... Clemenceau salía a flote. Recién, pues, nacía La Aurora...

Tristemente apoyado de codos, saboreando mi ajenjo, pensaba en la "Isla del Diablo", Pencel Semitismo, eencel Anti-semitismo, j en el ejército; en todos aquellos nombres que, aunque viejos, adquirían para los oídos de París ávido i ante los ojos del público, la novedad de una cábala que había que decifrar "a outrance"...

" Compuez Zolal" ¿Por qué vociferaban así contra aquel hombre que en un arranque de altruísmo supremo, sediento de justicia, había lanzado a la faz del mundo un anatema, condenando una abominación?... Se hablaba de Semitismo, i la faz jacobita de los hijos de Abraham, metidos dentro de su gabán de pieles en el peristilo de la Bolsa, inquietaba al público. Se creía en un poder oculto, que secretamente, i a fuerza de "talentos", iba a operar una redención... I la redención molestaba a Francia. Se la había herido en lo más noble, i protestaba el coucardierismo parisiense... ¡Zola pagadol...

Por otra parte los Inmortales, encontraban también una coyuntura $i$ el ejército, aferrado al sable curvo de aboukir, reclamaba las glorias de Bonaparte en Égipto...i así estaba yo aquella tarde, metido dentro de mi hulster marrón, pensativo y triste, espe- 
rando noticias. El remolino del público crecía i las aceras desbordaban. Por todos los puntos negreaba el pavimento, i las luces de los cafés, que ya empezaban a encenderse, abrían boquetes luminosos en los edificios. Era la "hora verde", i el absinthe coronaba la tarde. En las mesas, alineadas erı las terrazas, los habitúes: caras conocidas que trasponen los mares en las fotografías de los panoramas, comentaban los últimos hechos; i en la larga perspectiva del boulevard, entre el remolino de los transeúntes, confundíanse zozobrantes los discos de las mesas, donde chocaban las copas... En un grupo, junto a un gran sombrero con plumas, la silueta de Aureliano School se perfilaba con una orquidea en el ojal. Hierve la Chausée d'Antin y al caer de las hojas, en la tarde mortecina y triste, el descorchar de las botellas en los Bars, el sonoro rodar de los carruaies y la aparición de los ómnibus, lentos i atestados de gente, adquieren el sello cómico de un desfile de títeres, entre el amarillento chispear de los mecheros de gas i un letrero en colores que auncia las marionetas de Roberto Roudin para la noche... Una florista aproximando un clavel rojo a mi butonniére, intenta ponérmelo; la rehuso, coje su cesta de flores que ha dejado sobre mi mesa, hasta perderse tras un kiosko. Desfislan tres trotinnes cojidas de la mano y junto a mí, una grisette que lleva la falda recogida y una caja de cartón al brazo, llama a un joven melenudo que usa un gran sombrero de fieltro negro, su p'tcochon. En ese momento pasa el ómnibus de Montmartre. Son las seis. Al frente, un camelot, con voz chillona ganguea desde una esquina:

-iL'Aurorel

Me incorporo.Jorge Puccinelli Converso»

Luego otro, diez, veinte...

-A ver; uno cualquiera...Tú ¡Psch!

Caen tres. Doi un sou al más pequeño, despliego mi hoja y me preparo a leerla, cuando el toque de la bocina de un automóvil que pasa y varios gritos, me hacen volver el rostro. El público se arremolina. Detenido trepida el automóvil; i con la mano en la palanca, el chauffeur maniobra con cuidado. La placa del cinturón de un policía reverbera entre el grupo. Me inclino. Es el camelot, que ha perdido un brazo.

I bajo las ruedas alcanzo a ver su mano que, lívida, estrecha aún mi sou.

(En Actualidades. Lima. Año I. No. 16. Abril 28 de 1903). 


\section{LA PARED DE ENFRENTE}

En el fondo de un patio, habitaban una modesta casita, la madre i una pariente materna ya mui anciana - su tía i tía abuela respectivamente- a quien acababan de recoger.

La hija era todavía mui joven, en la efímera frescura de sus dieciocho, cuando habían tenido después de sufrir reveses de fortuna, que encerrarse allí en el rincón más apartado de su mansión paterna. Todo el resto de la querida casa, toda la parte que daba a la calle, había sido necesario alquilar a unos extraños, profanadores, que cambiaban el aspecto de las cosas antiguas i destruían los recuerdos.

Una venta judicial les había quitado los muebles más lujosos de otros tiempos i habían arreglado su nuevo saloncito de reclusas con objetos un tanto heterogéneos; reliquias de los abuelos, antiguallas exhumadas de los desvanes, reservas de la casa. Así i todo, en el acto le tomaron cariño a ese salón humilde que, durante años, las había de reunir a las tres junto en un mismo hogar, alrededor de una misma lámpara, durante las veladas del invierno. Se encontraban bien allí, había un aire familiar e íntimo. Uno se sentía enclaustrado, es cierto; pero sin tristeza, pues las ventanas, con sencillas cortinas de muselina, daban a un patio lleno de sol, cuyas paredes mui bajas estaban cubiertas de madreselvas i rosales.

I ya se olvidaban del bienestar, del lujo de antes, felices en su modesto salón, cuando un día les dieron ung noticia que las sumió a las tres en la mayor consternación; el vecino iba a agregar dos pisos a su casa i se iba a levantar una pared enfrente de sus ventanas, a quitarles el aire, a dultarles lelosol...

T ningún medio, jayl se les ocurría para conjurar esa desgracia, más íntimamente cruel para sus almas que los anteriores desastres de fortuna. Comprar la casa del vecino, lo cual hubiera sido fácil en los tiempos de bienestar, ya no había que pensar en ello. Nada había que hacer en su pobreza, nada, sino doblar la cabeza.

Las piedras, pues, empezaron a amontonarse, ellas con angustia las miraban alzarse; un silencio de duelo reinaba en el saloncito, más triste cada día a medida que iba subiendo aquella cosa que todo lo obscurecía. I pensar en que esa cosa cada vez más alta, acabaría por remplazar el fondo del cielo azul o de nubes de oro sobre el cual, en otros tiempos, se destacaba la pared de su patiol

En un mes, los albañiles concluyeron su obra; era una superficie lisa, de piedras de sillería que luego fue pintada de un color blanco tirando a gris, que simulaba casi un cielo crepuscular de noviembre, perpetuamente opaco, invariable i muerto, -i en 
los veranos siguientes los rosales, los arbustos del patio, reverdecieron más raquíticos a su sombra.

En el salón, los cálidos soles de junio i julio penetraban todavía, pero más tardíos por la mañana i a la tarde desaparecían más temprano; los crepúsculos del otoño caían con una hora de anticipación, i originaban en el acto las penetrantes tristezas grises.

I al tiempo, los meses, las estaciones transcurrieron.

Al anochecer, en las horas indecisas de las tardes, cuando las tres mujeres iban dejando una tras otra su labor de bordado o de rostura, antes de encender la lámpara para la velada, la joven, que ya iba entrando en años, levantaba siempre los ojos hacia aquella pared construida allí donde antes había un pedazo de cielo: a menudo también, debido a una especie de puerilidad que se solía manifestar en ella, algo así como una manía de reclusa, se entretenía en mirar, desde cierto sitio, las ramas de los rosales, las copas de los arbustos destacarse sobre el fondo gris de las piedras pintadas i procuraba hacerse la ilusión de que ese fondo era un cielo, más bajo i más cercano que el verdadero poí el estilo de los que de noche pasan sobre las visiones deformadas de los ensueños.

Conservaban la esperanza de una herencia de la cual hablaban a menudo, sentadas en torno de la lámpara i de la mesa de trabajo, como de un sueño, como de un cuento de hadas, por lo lejano que parecían estar.

Mas tan pronto como recibieran la herencia que esperaban de América, por cualquier precio se compraría la casa del vecino con el fin de demoler la parte-nueva, restablecer las cosas a su estado de antes i devolver al patio, a los queridos rosales de las paredes su sol de antaño. Echar abajo aquella pared, había llegado a ser su sueño terrestre, su continua obsesión.

La vieja tía solía decir entonces:

- Hijas mías, quiera Dios que yo viva bastante para ver ese hermoso día.

La herencia, sin embargo, tardaba mucho en llegar.

Las lluvias, a la larga, habian trazado en la superficie lisa de la pared unas rayas negruzcas, de aspecto mui triste, que formaban una $\mathrm{V}$ o bien algo parecido a la vaga silueta de un pájaro que se cierne.

Cierta vez, durante una primavera mui cálida que, a pesar de la sombra de la pared, había hecho abrirse las rosas más temprano que de costumbre, un joven apareció en el fondo del patio; durante algunas tardes se sentó a la mesa de las tres señoras sin fortuna. De paso en la ciudad, había sido recomendado por amigos comunes, no sin la vaga idea de un casamiento posible. Era hermoso, con mucho donaire, con el rostro curtido por los vientos de mar... 
Mas, consideró demasiado quimérica la herencia i demasiado pobre a la joven, cuya tez empezaba a palidecer por falta de luz.

Así es que se retiró para no volver, el que durante un tiempo había representado en la pobre casa el sol, la fuerza i la vida. I la que ya se había creído prometida suya recibió con esa partida un mudo e íntimo sentimiento de muerte.

I los años monótonos siguieron su curso, al par de los ríos impasibles; trascurrieron cinco, i luego diez; quince i hasta veinte. La frescura de la joven sin dote desapareció poco a poco, inútil i desdeñada; la madre acabó por tener canas; la vieja tía, inválida, cabeceando, octogenaria, se quedó clavada en un sillón, eternamente sentada en el mismo sitio. cerca de la ventana, destacando su perfil venerable sobre el fondo de la pared lisa, en la que iban acentuándose las rayas negruzcas, en forma de pájaro, trazadas poco a poco por el agua de las goteras.

En presencia de la pared, de la pared inexorable, las tres envejecieron. I los rosales i los arbustos, envejecieron también, pero de un modo menos siniestro, côn amagos de rejuvenecimiento a cada primavera.

- ¡Oh! hijas mías - repetía la tía con su voz quebrada que ya no concluía la frase- con tal que yo viva bastante, para...

I su mano huesosa, con ademán de amenaza, señalaba la horrible pared.

Murió .sin embargo, dejando en pos de sí un vacío horroroso en el pequeño salón de las reclusas. La habían llorado como a la más querida de las abuelas, cuando por fin llegó la herencia, un buen día en que nó sè pensabalen ella.

La hija, que ya habia cumplido los cuarenta años, se sintió toda rejuvenecida, en medio de sul alegría de entrar en posesión de una nueva fortuna.

Naturalmente se despediría a los inquilinos i se volverían a instalar romo en otros tiempos; pero permanecerían más a diario en el saloncito de los días de pobreza; en primer lugar, estaba lleno de recuerdos; luego volverían a tener su alegría llena de sol, tan pronto como se hubiese echado abajo aquella pared de cárcel, que ya no era un vano espantajo, fácil de destruir con luises de oro.

Al fin, tuvo lugar la caída de la pared, anhelada desde hacía veinte años. Fue en un mes de abril, en el momento de las primeras brisas tibias, de las primeras tardes largas. Aquello se hizo mui de prisa, en medio de gran ruido de piedras que caían, de obreros que cantaban, entre una nube de polvo. En la tarde del segundo día, cuando todo hubo concluido, cuando los obreros se hubieron retirado i se estableció el silencio, otra vez se hallaron sentadas ante su mesa, la madre i la hija, asombradas veían que había tanta claridad i que ya no necesitaban lámpara para em- 
pezar la comida de la tarde. Como en una extraña vuelta de tiempos anteriores, miraban florecer los rosales de su patio bajo un cielo verdadero. Pero en lugar de la alegría con que habían contado, fue aquello primero un indecible malestar; era demasiada luz la que inundaba de pronto el saloncito, un resplandor triste i la noción de un vacío inusitado afuera, de un cambio inmenso... No encontraban palabras, en presencia de la realización de su ensueño; ensimismadas una i otra, embargadas por una melancolía creciente, se quedaban sentadas sin hablar, sin probar la comida servida, i poco a poco sus corazones se oprimieron más i empezaron a experimentar algo semejante a un profundo desamporo.

Cuando la madre notó que los ojos de su hija se llenaban de lágrimas, adivinando los pensamientos que tanto debían parecerse a los suyos:

-Podríamos construirla de nuevo - dijo. Me parece que podríamos intentar levantar una pared igual a la otra. ¿No te parece?...

-En esto mismo pensaba, contestó la hija. Mas, no; no sería ya la misma pared.

¿Cómo? Ella era, sin embargo, la que había decretado la destrucción de ese fondo de cuadro familiar sobre el cual, durante una primavera, había visto destacarse un hermoso rostro de joven i durante tantos inviernos el perfil venerado de la tía muerta...

I de pronto ante el recuerdo de ese vago dibujo en forma de, sombra de pájaro, trazado por el agua de las goteras; ique ella no volvería nuncả à yero su corazón secdesgarró de un modo atroz, lloró las lágrimas más crueles de su vida, ante la irreparable destrucción de esa pared-que para ella erá el pasado, la juventud i la esperanza.

(En Actualidades. Lima. Año I. No. 26. Julio 14 de 1903).

\section{EL PASADO MUERTO}

Bajo la amplia ventana de vidrios polvorientos del comedor, enfrente uno de otro, don Faustino i doña Ascensión meditabun.

Era la hora del crepúsculo, en la que el corazón oprimido de los dos viejos elevábase hacia el pasado, hacia sus primeros días, días lejanos, cuando Faustino rubio i guapo, de veintidós años, conoció a Ascensión, de dieciocho, morenucha i vivaracha, con grandes ojos pardos i fogosos; i la iglesia de San Joaquín atronó el pueblo con el vuelo de sus campanas i el estallido de los bom. bardones desde las torres... 
Sí, todo pasa, todo desaparece ante los rigores del tiempo, i la juventud, flor efímera de la vida, sólo guarda para la ancianidad su desvanecido perfume, cruel i evocador!

I ante estas reflexiones, dichas por el pobre viejo, con voz trémula i sollozante casi, doña Ascensión enmudece, puestas las manos temblonas, de nudosas falanges, sobre los brazos de caoba de su sillón de baqueta.

$\mathrm{El}$ espíritu de los dos viejos se remonta a épocas lejanas i conserva, grabado en la memoria, el recuerdo aquel de sus días felices, de sus amores de tórtolas, bajo el verde emparrado de la casa, donde la tía Ursula, jovial i regordeta siempre sonríe contemplando sus plácidos amores... Piensan en su vida feliz e igual en sus días serenos, transcurridos como un manso río bajo el toldo esmeraldino de la parra...

Las mozas volvían del pueblo, lento se recogía el ganado al son de sus esquilas, i en la carretera grupos de campesinos con el rejón al hombro, proyectaban sus sombras corpulentas a lo largo de las landas. Aquello había sido la suprema dicha. ¡Cómo, Ascensión, robusta i pletórica, desbastó las formas primitivas de su cuerpo adolescente, el grueso tronco de sus pantorrillas i su cintura de zagalotel Parecíale a Faustino estarla viendo; i ante estos recuerdos felices de su juventud, brillaban sus pupilas grises de cabra, su labio inferior temblaba i conmovíase todo su ser...

Pero un viento de inclemencia había pasado por ellos, arruinando sus cosechas i reducídolos a la triste condición de simples arrendatarios: cambiando la topografía de sus campos, borrando la hisella de los caminos tantas veces trillados por ellos i, sacando las parras, implantando en pleno corazón de su propiedad una refinería de azúcares de remolacha. Hoy el continuo batir de las máquinas perturbaba su reposo, las chimeneas ahumaban el azul sereno i límpido de su cielo i grupos de operarios, de zarza azul. alborotaban los patios desde temprano.

- Será preciso - dijo don Faustino, rompiendo el silencioprevenir al dueño de lo que pasa... Ya no se puede estar. Todo lo ensucia el humo i, si no levantan las chimeneas, acabaremos por asfixiarnos.

La vieja repuso conturbada:

-Es...que va para un año que llevamos corrido el alquiler, i jtú sabes lo que es ese hombrel

Ante esta observación don Faustino enmudeció recordandn, en efecto, que aquel día el plazo: jun añol...Tal día como ése tenían aún el cortijo.

— ¿Recuerdas, Ascensión?...A no habérsenos muerto todos los animales, hubiéramos podido dárselos en pago.

Luego, tristemente, se puso a meditar, revolviendo los dedos 
índices a la par que sus ideas. De pronto hizo un gesto i levantó los brazos.

Ascensión lo miró con angustia.

-No, nada - dijo_. Es que recordaba que hoy, justamente, hace cincuenta años de nuestra boda... ¡I pensar que en nuestro aniversario estaremos quizá en la calle!

Una lágrima opaca se detuvo en el borde de sus párpados enrojecidos i sin pestañas; trató de incorporarse i se dirigió con lento paso hacia donde su mujer.

-Dios no lo permitirá —díjola-. Aun nos quedan muebles: viviremos en el suelo limpio. Después... serán nuestros cadáveres lo que. saquen.

I dándole un beso, quedaron unidos en un tierno abrazo. Un temblor senil recorría sus cuerpos, i gruesas lágrimas rodaban por sus mejillas, como por un muro en ruina. Sus pechos se agitaban, i bajo el ventanal sus cuerpos unidos proyectaban una sola sombra.

En ese momento llamaron a la puerta. Era el dueño con tres alguaciles, que iban a realizar el embargo.

Ante proceder tan violento, miráronse atónitos los dos viejos. Luego suplicaron, pero todo fue inútil. Un notario practicó el embargo. I ante las puertas de la fábrica, en el patio mismo de su antigua propiedad, el dueño, inexorable les marcó el camino de los campos.

—Es allá —dijo extendiendo el brazo_, donde deben habitar los tramposos... iBastante hago con no mandarlos a la cárcel!

Sonaba el ángelus. El sol poniente doraba los campos i tras las colinas pronto vieron los esposos proscritos lleqar la noche i desaparecer las luces del pueblo.

El camino a la casa de Ursula era lóbrego, aguas estancadas espejeaban en la sombra i un hálito de desolación se extendía en tormo. Pronto se cansaron. Sentados sobre una piedra, quedáronse meditando, cuando un canturreo alegre rompió el silencio i les hizo incorporarse: era un pastor que conducía un rebaño de cabras, que reapareció entre las zarzas.

— Vienes de Medún? - preguntóle Faustino.

- Sí -repusó el pastor.

- ¿Conocerías a Ursula Febal?

—¿Ursula Febal?...¿la "regordeta"?

-Sí...

- ¡Âh! Aguarden ustedes... ¡Murió para la Porciúncula!

Arreó sus cabras y desapareció entre las sombras.

Lejos, mugió el ganado en los establos.

(En Actualidades. Lima. Año II. No. 55. Febrero 22 de 1904). 
Es domingo i estamos en las primeras horas de la mañaria" cuando Lima culinario bulle en los mercados i la gastronomía casera va de un puesto a otro en la confección del plato "extra"...

Pero he aquí que las parroquias tocan a misa y ya empieza a transitar la gente con animación... Son las diez. Es entonces cuando las iglesias se inundan con las primeras olas perfumadas y frescas de los devotos $i$, cuando la sociedad, ya en pie, recibe el Domingo en toilette aristocrática.

Dentro de las amplias naves, envueltos en una atmósfera mística de incienso $\mathrm{i}$ entre olores mundanos, asistiremos al desfile de la multitud femenina en un renuevo incesante de colores i de perfumes; de frescura de lociones matinales i calidez de soles meridianos. Concluida la misa, las iglesias convertidas en un bazar de modas, vacías en los atrios el remolino de faldas i encajes de las damas, donde naufragan las rígidas figuras endomingadas de los hombres situados como maniquíes a las puertas. Pululando por las calles, invaden la ciudad, alegres, radiantes, llevando en el pecho junto con el "pésame" de los kiries, el regocijo del ite misa est de un domingo bullicioso de alegres proyectos. En las arterias urbanas las largas filas desbordadas de los templos semejan a lo lejos una colosal serpentina arrolladora de iglesias. Se pueblan las calles. Mercaderes, Espaderos, La Merced, el jirón íntegro, se convierte en una carrera triunfal de trajes vistosos i ajustados talles, de faldas frufutantes, de correctas levitas, de relucientes sombreros de felpa, de audaces corbatas... L Los almacenes adquieren nuevos gspectos das joyerías raras sonrisas, mostrando desde el fondo de sus estuches abiertos como bocas el cristalino brillo de sus dientes facetados... El jirón aristocrático convertido en un corso, ofrece el animado aspecto de un pasacalle. Situados en una esquina, veremos desfilar entonces el Todo-Lima. Por allí pasará el ministro reciente como un nuevo sol con su zodiaco de íntimos, exhibiendo la novedad de su cartera; el saliente, con los términos de su renuncia formulada; los que estuvieron en inminencia de serlo; los que lo están a perpetuidad i por último, los que pasean su "crisis" i hasta los interpelados, paradójicamente mudos. Al Mercaderes político seguirá el social, con el de los nombres "conocidos", llevando el eco de la sílaba final de sus patronímicos. El femenino, arrollador, graciel, ligero, envolviendo en una mirada a los concurrentes; destacando las plumas de su sombrero i el chantilly de las basquiñas por sobre un mar de cabezas; con las faldas recogidas, luciendo el agudo taco de sus botines, en un perpetuo cambio de saludos, de inclinaciones de cabeza contra. solemnes chisterazos. Ante las puertas, en las aceras y en las esquinas los elegantes frescos, acabados de afeitar i 
en traje de fiesta, forman barreras con sus cuerpos, adosados a las vitrinas como un réclame a los almacenes. En la calzada, los tranvías llevando la avalancha de sus pasajeros dominicales, vaciándolos en las conexiones, arrastrándolos hasta la Exposición con sus boletos directos...

Maremágnum de carruajes, de vendedores de diarios, desbordes de gente, carreras de ciclistas de record, trote de cabalgaduras de sportman, de caballos criollos, de gendarmes... i al norte, abierta como la boca de un horno, la plomiza arcada del portal de Escribanos estrangulando a la multitud salida de los Bonmarchés i del Estrasburgo, i encauzando a la que viene del Puente con las pilastras de sus cuarenta arcos. Luego el otro portal con el tajo de Petateros, abierto como una angosta y obscura esclusa hacia los brillantes escaparates de Nove, en Plateros, desde donde se entrevé la Plaza de Armas bajo el sol de la mañana como un cromo de primeras tintas.

Cuando la campana de San Pedro bordonea las doce, la algidez de la fiesta decae. Las iglesias reciben el nuevo contingente para las dos últimas misas. La concurrencia se desbanda lentamente i por todas partes se opera el reflejo de la multitud en un movimiento de descentralización. Es la hora del almuerzo. Los restaurantes reciben en albo mantel de sus mesas de domingo los contingentes salidos de los Bars; i la limeña almuerza con mantilla para la misa de una, con las mejillas ardientes por la agitación de la mañana i la vista fija en el reloj, con la zozobra de la misa comenzada. Este hacecillo de nervios no descansa: quiere verlo todo, oírlo todo, concurrir actodas laseíglesias, asistir a todas las misas, estar en un mismo tiempo en todos los sitios; tiene el don prodigioso de la ubicuidad neurótica, i moriría si no hiciese su domingo completo.

A las tres recién da reposo a su actividad locomotriz muellemente reclinada, recapitula su febril mañana reconstruyendo en su imaginación, tal vez preocupada, las notas salientes para su carnet del día; un detalle, la flamantez de un vestido, el chispear de una joya, el espejeo de un sombrero de felpa al sol, en el atrio de una iglesia; un rostro insinuante, la incisión de las largas guías de un bigote abrillantinado, la estrechez de un pantalón destacando un botín de charol plano o la nota llamativa de una corbata decadente...

A las cinco ya está en toilette de tarde: Entonces la veremos tan fresca como en la mañana, recorrer al trotelargo en sus caballos el Paseo Colón, describiendo con las ruedas de su carruaje una curva cerrada, entre el brillante espejeo de los arneses i el chasquido de la fusta; detenerse al pie de los sardineles, contemplar la concurrencia, i proseguir el corso. Al pie, arrolladora y simple como la falda recogida, calzado el guante y erguida la cabe- 
za, sustentando con la cracia frágil de su pivote de sombrerería su sombrero de grandes plumas. Andaluza, tiene para cada admirador una chispa; madrileña, para cada saludo una inclinación cortesana; morisca, los arabescos de sus encajes, las granada de sus labios i las nostalgias de la Alhambra.

Al brillante resplandor de nuestros soles poniente, en el rojo incendio del oeste, aspira los efluvios con que la brisa marina de los balnearios refresca sus mejillas. Sonríe ante el recuerdo, i busca entre la multitud el tipo de sus caprichos del día.

Cae la tarde y el sol se pone. Envuelta en los dorados reflejos de una luz de apoteosis, parte a su casa.

El parque vacío queda envuelto en la tristeza crepuscular destacando sobre la línea cárdena y vigorosa del horizonte el artesonado frontis de su palacio blanco y la prismática punta del obelisco gris. Los árboles, las plantas, los asientos, se cubren de relente salino del mar y los focos eléctricos, rasgando sus párpados, iluminan el paseo solitario.

En la noche sigue su carrera en el teatro. Sentada en un mal palco de ventorrillo, gozará con el espectáculo de la zarzuela popular a falta de otro. Es ingenua y le gusta escuchar, reirá ante el epigrama, salvando con un mohín las escabrosidades del "género chico", ocultando tras las plumas de su abanico la línea de sus labios de comisuras maliciosas. Por lo demás se luce, destaca su hermoso busto: ve i es vista. Lleva las lunas de sus gemelos asentándolos de palco a palco, descendiendo hasta la platea, trepando hasta la cazuela... .se divierte, ríe...i se va a dormir, después de hacer escalo en algunas de las confiterías que velan en la espera del último contingente de los teatros.

(En Actualidades. Lima. Año I. No. 12. Marzo 28 de 1903).

\section{LA CALLE}

(Para el lápiz de Sixto)

Cuántas lecciones encierra la calle para los espíritus observadores. Para Balzac, fue siempre una fuente de observaciones agudas. No hai artista que no la deba lo mejor de su vida. Podría escribirse todo un tratado: "El Alma de la Calle". A ella debió Gavarini sus geniales producciones, los Goncourt lo mejor de sus notas, Daudet un cúmulo de observaciones, i cuando Balzac decía que habían necios que andaban con las piernas abiertas i luego se admiraban de que un perro pasase por entre ellas, establecía todo un punto de psicología callejera...

Si detenidos en una esquina vemos como veía el autor de La comedia humana a cada transeúnte, acabaremos por descubrir 
como éste, en la monotonía aparente y odiosa del ajetreo diario, todo un cúmulo de observaciones a cual más agudas o dolorosas, cómicas o tristes, torpes o espirituales. Véis a ese sujeto qordo que camina con un aire de buci taimado, de triple rebarba, aprisionando entre sus manos redondas como bollos un pañuelo de hierbas mientras su amplia chistera reluciente como una chimenea de alquitrán gravita sobre un craso cogote con cenefas de carne: Un librero. I aquel otro, famélico, inquieto i enfundado dentro de un jaquet negro, que lleva los brazos descolgados, aprisionando los pulgares contra los índices, bajo los puños raídos de su camisa?: Un amanuense.

El otro, de grandes pabellones como paletas de pintor corbata salmón i una cadena de dos vueltas en el último botón de su chaleco escotado: un hortera. Un agente de pleitos aquel que rubrica en el vacio. Un cambista el otro que cuenta la guita rascándose la palma de la mano como si le picara una pulga. I esa señora gorda que camina con sus hijos prendidos de las manos, como una cadena de renacuajos que salva las bocacalles remolcando el cordón de su prole y capeando los fiacres?: Una madre de las afueras. La flaca, aquella que trasporta un descomunal som. brero atravesado por una pluma de pavo, una cursi que luce; la que la acompaña, una tía atrapada en la vecindad, con una esclavina como un caparazón de tortuga; ese alto con aspecto de caballo de fiacre, un estoico al que los transeúntes zarandean como el viento a una caña. Aquel mofletudo, bermejo como una puesta holandesa de sol, con las sienes prominentes i trituradoras mandíbulas, un tragón detrestaurant a preció fijo; el otro, un agente de policía; un abogado el más allá

I así en la cinematografía callejera, la vista os irá mostrando caras afligidas, perfiles de sátiros de retablo, gentes fofas como colchones deshechos, hombres escurridos, patillas de sargazos, narices husmeadoras de perro pachón, curvas cual picos de águila, ojos de besugo, dientes de foca, calvas que descubre un saludo, manos hiperbólicas, pies torcidos, piernas canijas, brazos cortos, cinturas de ciudadela, hombros plataformas i todas las deformidades de la vida que a diario se codean con nosotros, se sitúan a nuestro lado i cuyos órganos desplegan la misma mecánica actividad que las piezas de una máquina puesta en marcha. Por cada rostro bello, por cada perfección relativa, encontraremos deformidades mil, tristezas humorísticas a los que el lápiz podrá sorprender con un rasgo característico i hacerlas perdurar en ese epigrama del carbón que se llama caricatura. A ella os dejo amigo Sixto la travesura del vuestro: caricaturizar es sicologizar con la risa de Voltaire... o llorar como Pierrot, con una mueca.

(En Actualidades. Lima. Año III. No. 94. Enero 14 de 1905). 


\section{EL ARTE OHINO EN LIMA}

(De Tiendas)

Entre las fases que la colonia china nos ofrece aquí, hai una nota simpática i original; i esta es la de los bazares. El arte asiático se presenta en ellos con toda la gracia sutil i vaporosa de sus telas, la fastuosidad imperial de sus biombos bordados de oro, la coquetería de sus juncos i esterillas, i la alegría sonriente de las lacas, farolillos y flores de melocotonero talladas en las cenefas de sus mostradores.

Con un poco de imaginación, el que recorra estos bazares podrá apreciar la habilidad de mano i el arte supremo de esta raza hábil entre todas.

Hasta hace poco, sus industrias mercantiles sólo se habían limitado a la venta del té, mantas de vapor bordado i uno que otro chisme artístico, entre los que figuran esos famosos secreters de laca que todos hemos conocido en las casas antiguas, con sus sugestivos aldaboncillos de metal blanco i vidriado barniz rojo i negro; o a cajas de manta, con pies adaptados por la habilidad criolla de algún carpintero local o a juegos de mesitas para el ajedrez. Salvo ligeras variantes, su comercio permaneció tal como le conocieron nuestros abuelos; con sus aguas de "Kananga" para el tocador, polvo de menta para los dientes, escobillas, peines i otros objetos de concha o marfil. Hoi este comercio ha evolucionado i sus almacenes muestran los refinamientos de un arte más inteligente i eurepeizado. sil seme permite la frase. Antes, una limeña exotista sólo podía hallar en ellos sus mantas bordadas, un barquito de marfil con su fanal de vidrio para la consola, tarros de té de blando estaño con que rizarse los "cachitos" i peinetas de carei para sus bandós. Su coquetería, hallaría ahora campo vasto para fantasear, recorriendo sus escaparates bien provistos i exhumando objetos chinescos del gusto más refinado; los hombres poco dados a ir de tiendas, aprenderíamos algo del arte asiático i discurriendo con los bolsillos provistos, podríamos trocarnos en provisionales mandarines, amueblando un cuarto chinesco...

Es de notarse, a la vez, que el arte chino, única importación bella que nos ha venido del Asia, se funde i mezcla hoi con el niponés i coreano. Así, a la pureza de pulimento de las Iacas, a la liturgia de sus bronces, a la fastuosidad de sus telas recamadas, únese el bambú de los muebles japoneses, la aplicación de la esterilla a la ebanistería i el cristal bicelado a los espejos. Indistintamente, hallaremos confundidas porcelanas chinas con japonesas, telas de Nankín con sedas pekinenses, conchas i marfiles de una i otra parte. La China, pues, evoluciona i el arte asiático adaptado a las exigencias modernas, rompe sus antiguos moldes i toma vue- 
los más amplios. ¿Ha perdido por eso su encanto i originalidad, desapareciendo para nosotros esos recuerdos de antaño, en que sobre las polvorientas consolas veíamos palpitar diminutas tortuguitas con los arandeles trémulos de sus patitas bajo un cubrepolvo de vidrio, barquitos de marfil curvos como babuchas turcas, "rompecabezas" de sándalo i azules quincallas? Sí; pero hemos ganado en refinamiento. Hoi, las mantas de vapor bordado han quedado relegadas sólo a las "chinas", i nadie osaría destruir el esmalte de sus dientes con los polvos de menta del chinito pregonero, ni perfumarse con Kananga del Japón. Las damas encuentran telas artísticas en qué cortar sus blusas i el arte hermosos bronces, muebles ricos i porcelanas varias.

Con poco dinero, podremos instalar en nuestros hogares una exposición chinesca, llenar el vacío de un mueble i colocando un Daikoku o un Otei, derramar sobre nosotros los atributos de los dioses de la "Buena Fortuna"...

(En Actualidades. Lima. Año II. No. 8. Octubre 21 de 1904).

\section{ART NOUVEAU}

Es verdaderamente el "Arte nuevo" un nuevo arte, o es la expresión compleja de todas las artes a las que la vida moderna ha impreso la tormentosa espiral de un anhelo que surge a través de todo lo conocido en busca de una nueva fórmula? Es ambas cosas a la vez. Mezcla arcaicac de do antiguolis de lo moderno, participa a un tiempo de la simplicidad griega la recta- i del decadentismo bizantino en el que la concepción, zozobrando en curvas excéntricas, se complica i dificulta en una red de arabescos i macarronis, es cortada súbitamente en los vuelos de una curva o zigzaguea cual una sierpe a través de un detalle las más veces.

I como resultante de esta nueva fórmula, como consecuencia de ese anhelo de los espíritus hacia lo nuevo e incógnito, adquiere un sello litúrgico i casi teosófico; i después de arrastrar el espíritu en el vuelo amplio de una curva o desperezarse en un remate, se complica i escapa o vuelve, como el alma actual, cansada de una lucha estéril, al tipo primitivo, al prerrafaelismo sosegado de una doctrina de líneas simples, de la que la curva es solo una perversión.

I es que, en la psicología del espíritu moderno, en ese desvío del tipo primitivo que los siglos han retorcido i complicado hasta el infinito, flota, a través de todas las fórmulas i sistemas, un resurgimiento inconsciente hacia la Edad de Oro, hacia esa Arcadia a la que las almas torturadas ambicionan volver: no es sino el vano intento, la desesperanza de los espíritus retorciéndose en una nue- 
va fórmula, la que en el "Arte nuevo" puede verse; un momento actual, un ciclo de líneas desatentadas contorneando la idea principal, como contornean i arrollan las curvas de una voluta o un festón, los contornos sosegados de una columna de tipo corintio. Si examinamos una joya, un jarrón, un dibujo o un mueble, notaremos que, apesar del maremágnum de la composición en el tipo puro- siempre surge lo sosegado del motivo, la sensación serena i casi mística, que es su característica; i cuanto más complicada sea la composición, más superfluos parecerán los detalles en idea esencial. Por eso este arte, en busca de una representación gráfica que esté más en armonía con el estado de alma actual, baraja el lotus amando su hieratismo religioso, enmaraña la pureza de una virgen prerrafaelesca, bizantina el rectóngulo, afemina la solidez de la recta, parte, divide i bifurca en locos espasmos la curva unigénita del círculo $i$, deshecho e insano, en un delirio de formas nueva; ; se retuerce i crea -alma opresa en la cárcel de las formas- vanas i enfermizas concepciones para volver, repito, a la sanidad primitiva, que es el anhelo inconsciente pero sentido de las neurosis artísticas del presente.

Si estudiamos el arte a través de las edades, veremos que éste ha sido en todo tiempo la resultante de los espíritus. Desde el arcaísmo primitivo i mitológico de las primeras épocas, hasta el naturalismo preconizado por Zola, siempre ha revelado un estado de ánimo. Ásí, en la Edad de Piedra, la arquitectura sólo conoció el Dolmen. En la Edad Gótica, el espíritu enfermo i cansado de las luchas i el fragor de las armas, replegándose, buscó con su alma dolorida i mística, len el arranque de sus ajivas o en el vuelo esmirriado de una columna, el firmamento al que alzó su prez. Después, Bizancio, corrompida i orfebre, enredo su alma decadente en los arabescos de un harem i modeló sus vírgenes en afiligranados códices, en los que María, la virgen pura de los católicos, zozobró entre las complicaciones del arabesco. I así desde Fidias hasta Miguel Angel; desde Sebastián del Piombo hasta Murillo. Velázquez o Puvis de Cavanne, el arte, cualquiera que haya sido su forma gráfica, siempre reflejó el alma de una edad. Tuvo estancamientos que lo fueron del espíritu, o inconscientes regresiones al pasado en busca de un ideal; pero siempre imprimió su sello a una época. En el momento actual, cristalización razonada de todos los siglos, este desatentado pandemónium de todas las escuelas, de todas las teorías, de todos los sistemas que han conmovido el mundo, tratando de hallar su fórmula, piérdese en un coos de complicaciones vanas i superfluas las más veces i, trocado en expresión filosófica, revela a los sentidos en formas gráficas su alma metafísica; i ya sea en un lienzo o en un simple vaso, arranca del espíritu la vaga extrañeza de lo sentido, que no se comprende, de lo vago, que no alcanza a definirse, de todo aque- 
llo que en nuestras mismas almas vanamente se agita en la conquista de un más allá; de ese eterno más allá sentido ya por los griegos en el alma sosegada de Platón i obscurecido hoi por las enmarañadas teorías de la metafísica de Kant i el doloroso malestar del pesimismo de Schopenhauer. Para mí, este es el "Arte nuevo": un estado de ánimo que, a través de las formas conocidas, tiende en una inconsciente regresión al alma antigua i crea, en sus desesperanzas, la vaga liturgia de un mós allá, imprimiendo a sus concepciones las nostalgias del alma moderna.

Esencialmente decorativo, toma de la flora la mayor parte de su belleza ornamental, que complica i retuerce en una selva de tallos vírgenes; del arte egipcio la solemnidad hierática del monolito i el mudo misterio de la Esfinge: la filosofía de la forma; del indú, la fastuosidad oriental de un poema de Valmiki i el simbolismo del culto budista, que borda en la cola de un pavo real de Vehivania $o$ extiende en el ramaje anhelante de una higuera de brazos del Migadaia. Del griego, la pureza eternal de la Hélade i la gracia serena i plácida de un Olimpo amable, en el que un vaso es una ánfora i un poema de plasticidad cada forma.

I así, siempre inspirado en motivos decorativos, cuando no le satisface la flora, busca el espíritu; mezcla extrañas teogonías e, irreal i absurdo, amalgama en un simbolismo fabuloso formas e ideas, cayendo a las veces es el arcaísmo primitivo de un arte rudimentario i bárbaro, en el que los objetos son conchas estratificadas, arcaicos idolillos los bibelots i fósiles los broches.

Difícil sería precisar la época de su arranque. Nacido de un común estado del espiritucactual, ha partido ala vez de varios puntos, imprimiendo a sus concepciones esa diversidad de formas i complejidad de estilos con que nos desorienta; así, en Italia aparece ligero i alegre, i constituyen el macarroni i la flora latina lo principal de su estilo; en Inglaterra, es el Home, lo excéntrico de la forma adaptado a las comodidades del mobiliario i la ornamentación de las casas, en las que Logan ha hecho un culto de las estufas i un altar de sus bedrooms sacramentables; en Francia, coquetón i escéptico, con reminiscencias cancanescas del Renacimiento i algo de japonista en el rococó. En Alemania, desprovista de las gallardías de la forma, más filosófica que plástica, más abstracta que artística, éste ha llegado al wagnerianismo de la forma, a una doctrina artística en la que, cuando Odin no crea cisnes i fabrica Loengrines i floridas Elsas, pone por entero su alma de conquistador teutónico, rudo i bárbaro. Es la que marcha a la cabeza del movimiento; i de ahí esa vaguedad rudimentaria en la forma i ese misterio teogónico de los vasos de Viena, el arcaísmo de las joyas de Munich i la liturgia de los muebles de Berlín...

(En Actualidades. Lima. Año III. No. 95. Enero 21 de 1909). 


\section{LIMA PINTORESCA}

(EI Cercado)

He aquí un barrio nostálgicamente alejado de la ciudad i en que parece haberse refugiado el espíritu tranquilo de una provincia.

Mientras nuestros pasos repercuten en el empedrado de las estrechas callejuelas con sonoridades desconocidas para el barrio, un viento perfumado refrescará nuestro rostro con una caricia balsámica, evocándonos recuerdos poéticamente adormecidos en la soledad del ambiente, en las huertas cerradas, en las casas vacías, en las paredes musgosas i polvorientas, sobre las que asoman los árboles i se descuelgan las enredaderas destacando su follaje bajo el azul de un cielo meridional.

El amor nos murmurará entonces al oído historias confidenciales; misteriosos cuentos de hadas donde alguna Bella tal vez oculta en una huerta solitaria, coje la rosa de los hechizos en el macizo de un rosal encantado; fugas de faldas en las perspectivas sinuosas de los jardines, lirismos a lo Fausto, entre el follaje espeso tras el cual, la diabólica sugestión azuza en carcajadas; mitológicas escenas en las que Cupido, con un haz de ramas por flechas, juega al amor hollando el césped de algún rincón virgen... En la soledad de este retiro, la imaginación buscará sombras con que poblar esta decoración provinciana donde parece haber caído el amor solitario de una Bovary en el discreto ambiente de alguna casa-huerta invadida por el müsgö.

Desde que penetramos a la plaza, nos sentimos trasportados a una provincia, oyendo el đaudo canto de los gallo's i contemplando el cuadro de casas que rodean la iglesia, en cuyo atrio se levantan los atributos de la Pasión en una cruz de madera festoneada por un sudario sobre el que, desde lo alto del INRI, un gallo de palo vigila la plaza.

Hai paredes blancas i puertas rojas, paredes rojas y puertas verdes, barrotes carcomidos de ventanas desquiciadas, balconcillos frágiles como cajas de cartón, decorando fachadas bajas con una mise en escéne de "género chico" por los que asoman tiestos con claveles o latas de petróleo donde florecen malvas de olor i geranios rojos; paredes conventuales, desoladas perspectivas polvorientas: casas cuyas diminutas arquitecturas i huertecillos entrevistos por una rendija de puerta, os harón pensar en moradores fenecidos o capellanía en litigio; pacíficas mansiones burguesas donde se desarrollan existencias con la sordidez de la hiedra: almas adventicias arraigadas a un tronco de árbol o a una planta favorita, dolorosamente enclavadas por la gota a la humedad de los ladrillos i aferradas a la modesta propiedad de algún viejo ca- 
serón de puertas desvencijadas; pobrezas de herrumbre, condenando sus vidas con un mohoso herraje en las puertas falsas i viviendo entre los cachivaches salvados de los lanzamientos... Todo un pasado de grandezas señoriales dolorosamente batidas por el tiempo i la gotera, caídas en el olvido de un barrio apartado i pobre!

Contrastando con el recuerdo de las cortesanías del Coloniaje i las galantes licencias presidenciales de la República; con las opulencias bizantinas de nuestros acaudalados i las locuras de la bohemia espiritual i genuinamente criolla de antaño, sólo se escuchará el bordoneo de alguna guitarra, en una jarana vulgar, donde el pisco corona la algidez de la parranda.

A este retiro limeño ha sucedido el barrio de extramuros circuido por restos de demolición, basurales i cascote, donde la belleza pintoresca de un detalle, una nota de color, un recuerdo, surgen dolorosamente confundidos.

Dejando la plaza dormida al rumor de una pila, entre un jardincillo inculto, pasamos al "Buen Pastor", embocando la calle principal donde se levanta un vetusto mirador como la torre de un muezzin dominando el barrio. Antes, en un ángulo de la plaza, un viejo caserón nos mostrará la enmarañada construcción de sus tres pisos, como un palomar vacío del que hubiesen emigrado las palomas de algún solitario colombófilo.

Llegamos al "Buen Pastor". Es este el lugar noveles de las reclusiones amorosas; atisbamos, pero nada! Tan solo se escucha el tenue sonido de un órgano i rumor de rezos, envolviéndonos en una atmósfera conventual i oponiendo a nuestra curiosidad la altura de sus murosila claveteada puerta de la iglesia cerrada. La psicología femenina nos asalta en este sitio con todos los misterios que encierra el corazón de la mujer. Con sus amores de colegiala impulsiva; con sus pasiones contrariadas; con sus sueños de ventura desvanecidos; con la rudeza de los padres; con la obstinación de las familias; con el desnivel de los maridos; con toda esa cadena sin fin de los procesos de amor, donde las conveniencias sociales troncharon un corazón desviándole de su primer rumbo i la falta de tino de un marido, las más veces, precipitó el corazón de una Honorina tras los muros de una reclusal ... Seguimos. Al otro lado se abre ante nosotros el asilo francés coquetamente pintado i ornado de flores, destacando las figuras de las religiosas en una perspectiva de vestíbulo teatral. Continuando por la calle del "Santo Cristo", pasamos por entre jardines metamorfoseados por la moderna floricultura, cuyas calles simétricas i meticulosamente limpias, delatan el jardín de paga, el precio recargado de la cerveza i el sandwich hostia; i llegamos al manicomio.

Aquí la Antropología guardando sus alienados entre negras rejas de presidio, delante de las cuales Hipócrates i Galeno, marmorificados, hacen su perpetua guardia en el patio. 
La nota dolorosa de la razón extraviada, el cerebro desquiciado, la secuestración médica. Todo un problema de alienismo debatiéndose entre las paredes de una casa de insania, que dirige, reglamenta i regula a extraños autómatas con uniforme, que gritan, gesticulan i amenazan desgarrar con manos crispadas las cofias planchadas de las monjas! I en el fondo, la ironía suprema de la vida en el tratamiento patológico, i el misterio de las almas...

(En Actualidades. Lima. Año IV. No. 752. 1906).

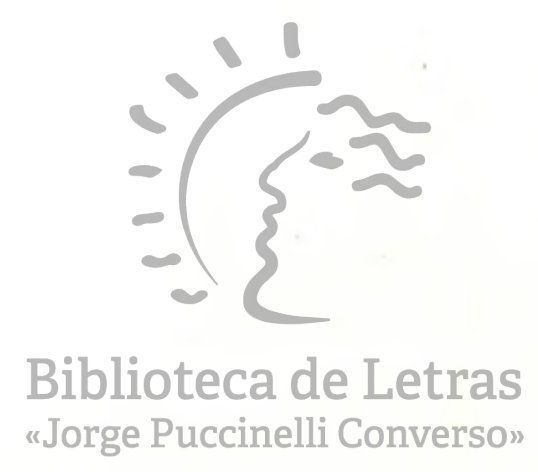

